\title{
Collecting eco-evolutionary data in the dark: Impediments to subterranean research and how to overcome them
}

\author{
Stefano Mammola ${ }^{1,2}$ (D) | Enrico Lunghi ${ }^{3,4}$ (D) | Helena Bilandžija ${ }^{5}$ | Pedro Cardoso ${ }^{1}$ (D) | \\ Volker Grimm ${ }^{6,7,8}$ (D) | Susanne I. Schmidt ${ }^{9}$ | Thomas Hesselberg ${ }^{10}$ | \\ Alejandro Martínez ${ }^{2}$
}

\author{
${ }^{1}$ Laboratory for Integrative Biodiversity \\ Research (LIBRe), Finnish Museum of \\ Natural History (LUOMUS), University of \\ Helsinki, Helsinki, Finland \\ ${ }^{2}$ Dark-MEG: Molecular Ecology Group, \\ Water Research Institute (IRSA), National \\ Research Council (CNR), Verbania, Italy \\ ${ }^{3}$ Key Laboratory of the Zoological \\ Systematics and Evolution, Institute of \\ Zoology, Chinese Academy of Sciences, \\ Beijing, China \\ ${ }^{4}$ Museo di Storia Naturale dell'Università \\ degli Studi di Firenze, "La Specola", Firenze, \\ Italy \\ ${ }^{5}$ Department of Molecular Biology, Rudjer \\ Boskovic Institute, Zagreb, Croatia \\ ${ }^{6}$ Department of Ecological Modelling, \\ Helmholtz Centre for Environmental \\ Research - UFZ, Leipzig, Germany \\ ${ }^{7}$ Plant Ecology and Nature Conservation, \\ University of Potsdam, Potsdam, Germany \\ ${ }^{8}$ German Centre for Integrative Biodiversity \\ Research (iDiv) Halle-Jena-Leipzig, Leipzig, \\ Germany \\ ${ }^{9}$ Institute of Hydrobiology, Biology Centre \\ CAS, České Budějovice, Czech Republic \\ ${ }^{10}$ Department of Zoology, University of \\ Oxford, Oxford, UK
}

\section{Correspondence}

Stefano Mammola, Laboratory for Integrative Biodiversity Research (LIBRe), Finnish Museum of Natural History (LUOMUS), University of Helsinki, Helsinki, Finland.

Email: stefano.mammola@helsinki.fi

\section{Funding information}

Horizon 2020 Marie Skłodowska-Curie Actions; Chinese Academy of Sciences, Grant/Award Number: 882221; Croatian

\section{Abstract}

1. Caves and other subterranean habitats fulfill the requirements of experimental model systems to address general questions in ecology and evolution. Yet, the harsh working conditions of these environments and the uniqueness of the subterranean organisms have challenged most attempts to pursuit standardized research.

2. Two main obstacles have synergistically hampered previous attempts. First, there is a habitat impediment related to the objective difficulties of exploring subterranean habitats and our inability to access the network of fissures that represents the elective habitat for the so-called "cave species." Second, there is a biological impediment illustrated by the rarity of most subterranean species and their low physiological tolerance, often limiting sample size and complicating laboratory experiments.

3. We explore the advantages and disadvantages of four general experimental setups (in situ, quasi in situ, ex situ, and in silico) in the light of habitat and biological impediments. We also discuss the potential of indirect approaches to research. Furthermore, using bibliometric data, we provide a quantitative overview of the model organisms that scientists have exploited in the study of subterranean life.

4. Our over-arching goal is to promote caves as model systems where one can perform standardized scientific research. This is important not only to achieve an in-depth understanding of the functioning of subterranean ecosystems but also to fully exploit their long-discussed potential in addressing general scientific questions with implications beyond the boundaries of this discipline.

\section{KEYWORDS}

anchialine, Asellus aquaticus, Astyanax, cave laboratory, computer simulations, experimental design, groundwater, model system, natural laboratory, nonmodel organisms, sampling strategy, stygobite, troglobite

This is an open access article under the terms of the Creative Commons Attribution License, which permits use, distribution and reproduction in any medium, 
Science Foundation; Croatian-Swiss Research Programme, Grant/Award Number: TTP-2018-07-9675; Ministry of Education, Youth and Sports of the Czech Republic, Grant/Award Number: LM2015075, EF16 013/0001782 and CZ.02.1.01/0.0/0.0/16 025/0007417

\section{1 | INTRODUCTION}

For a Homo sapiens-a clumsy vertebrate inhabiting a primarily lighted world-to enter a cave is enterprising. As the sunlight fades, the air becomes moist, and a maze of passages opens in front of us, our first instinct as humans is to dismiss the subsurface world as one of the most inhospitable environments on Earth. Mentions to this apparent extremeness emerge in most caving stories (MacNeil \& Brcic, 2017) insofar as speleology is indeed physically demanding and potentially hazardous (Zagmajster et al., 2010). However, by over-emphasizing this anthropocentric view of caves, we tend to dismiss a different reality: Caves are not so extreme from the perspective of the eyeless and depigmented organisms that have adapted to living in darkness, which in contrast experience the exposure to sunlight and the wide climatic fluctuation of the outside world as harmful threats (Mammola, 2020). Interestingly, this dichotomous interpretation has framed the two main approaches followed by researchers over recent years: Those who have studied subterranean habitats as unique entities versus those who have used them as model to answer general scientific questions beyond the boundaries of subterranean biology (Martínez \& Mammola, 2020).

Scientists across several generations have been aware of the potential of subterranean ecosystems (Box 1 ) as eco-evolutionary models (Poulson \& White, 1969), developing innovative methodologies and creative experimental designs to face the challenges associated with subterranean exploration. Thanks to these efforts, we have been able to tackle important subjects in ecology (Mammola, 2019), ethology (Parzefall, 1982), and evolution (Juan et al., 2010), ultimately reaching conclusions relevant to disciplines as diverse as medicine (Riddle et al., 2018; Stockdale et al., 2018; Yoshizawa et al., 2018), engineering (Lepore et al., 2012), and exobiology (Northup et al., 2011). Under this perspective, and despite the numerous obstacles to research, subterranean habitats may well qualify as frontiers for modern scientific research (Mammola et al., 2020).

In this work, we discuss the main impediments that we must address to standardize research in subterranean ecosystems and, subsequently, we illustrate old solutions, recommend best practices, and advance new frontiers to approach subterranean-based studies (Figure 1). By further elaborating on the established model organisms in subterranean biology, we seek to promote caves and other subterranean habitats as experimental arenas for asking general questions in ecology, ethology, evolution, and beyond. In other words, we call for moving caves from the niche of an exotic, understudied environment to the forefront of biological science. The gain

\section{BOX 1 A modern definition of subterranean habitats and implications for research.}

The term "subterranean habitat/ecosystem" is often used as a synonym for "cave" (Mammola, 2019; Poulson \& White, 1969). However, scientists have become aware that caves represent only a small fraction of the total habitat available to the subterranean fauna. More precisely, subterranean habitats comprise the breadth of underground voids of different sizes, either dry or filled with water, sharing two main ecological features: darkness and buffered climatic conditions (Culver \& Pipan, 2019). These voids may open a few centimeters below ground level (Culver \& Pipan, 2014) or descend several kilometers toward areas where the environmental conditions exceed the limits of life (Fišer et al., 2014). They are widespread on all continents, having been documented from different geological substrates, including carbonates (limestone and dolomite), sandstones, gypsum, granites, lava fields, iron ores, and even unconsolidated sediments (Keith et al., 2020). In summary, the cavities that we can access and explore by entering them represent just the tip of the iceberg of what lies below our feet (Ficetola et al., 2019; Mammola, Cardoso, et al., 2019).

Even though subterranean habitats are more widespread and diversified than it is usually recognized, subterranean research started with field observations in humanaccessible habitats (different types of terrestrial caves, artificial subterranean habitats such as mines and bunkers, lava tubes, cenotes, etc.), later encompassed pumped water (e.g., from drinking water wells), and only then extended to other difficult-to-access voids. Even today, there is still a significant research bias toward human-accessible habitats, which should always be kept in mind. In a nutshell, it implies that we may have to relativize part of the information available to date, that is, being aware that we have mostly documented how animals behave in cave-like environments, rather than in the extended network of fissures.

in doing so lies in the controlled conditions they offer, since they are little exposed to influences that one would have to control for in other environments. 


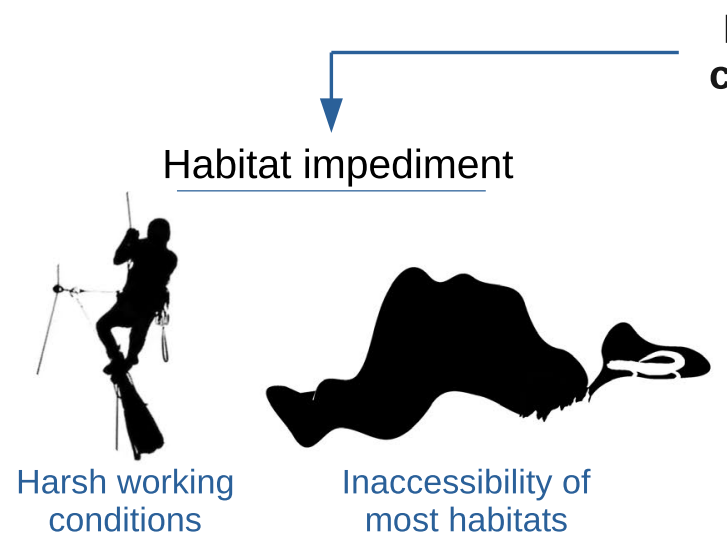

(a) (b)

\section{Research challenges}

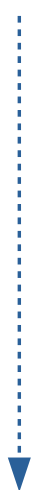

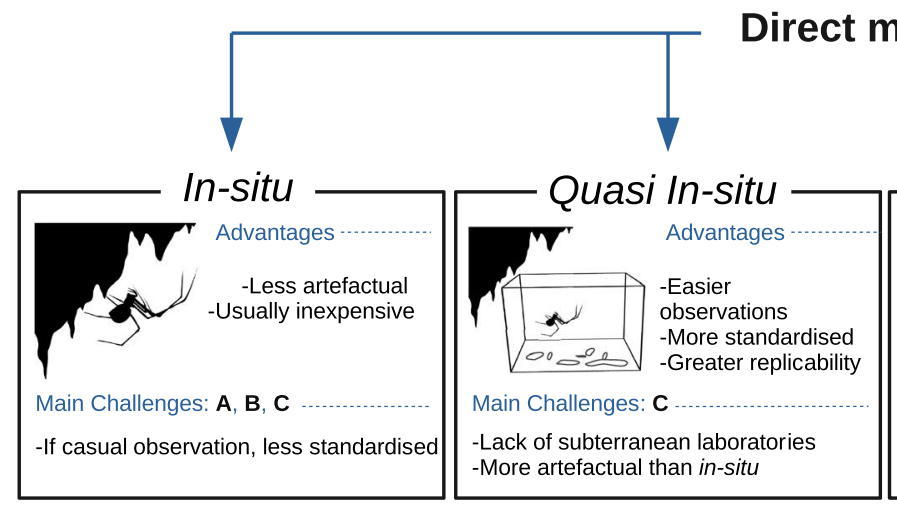

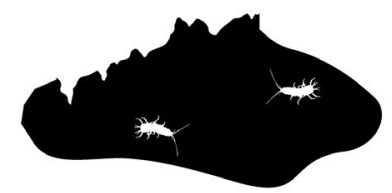

Low density (Low sample size and detectability)

(c)

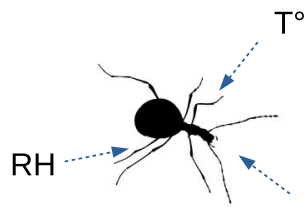

$\mathrm{pH}$

Breeding challenge (Limited plasticity; changes in life history)

(d)

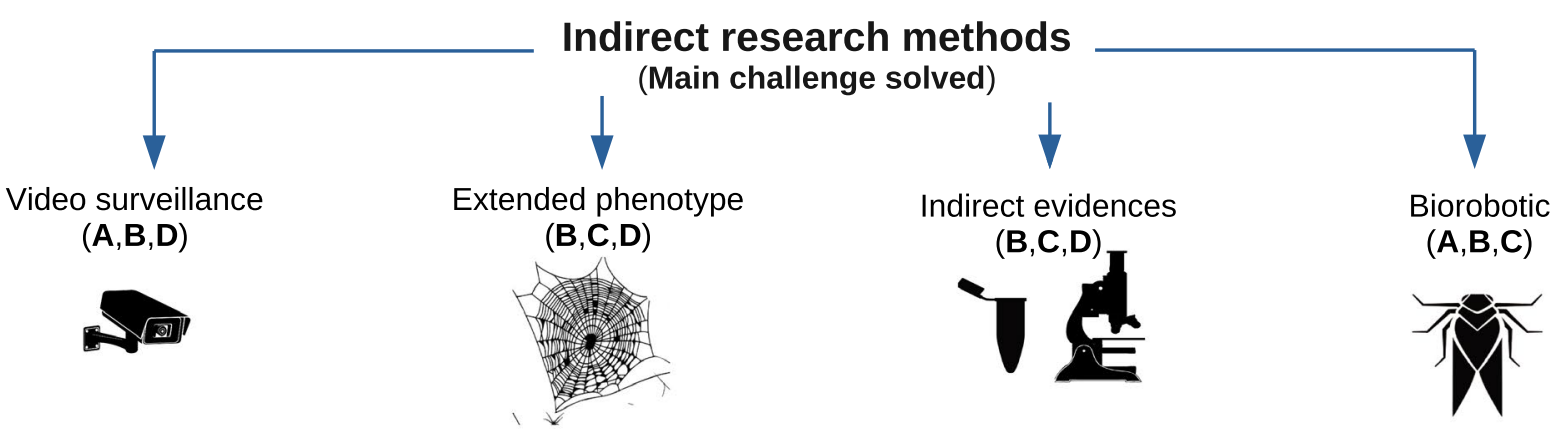

FIGURE 1 Challenges of subterranean research and experimental designs to avoid these. Schematic representation of the main challenges of subterranean research (coded with capital letters), and main experimental approaches that can be adopted to overcome these

\section{I RATIONALE FOR THIS WORK AND COMPLEMENTARY REVIEWS}

It is impossible to cover all methods in subterranean biology while keeping this review tight and comprehensible. Therefore, we decided to focus on the main challenges related to subterranean research and the philosophy underlying the different experimental designs suited to overcome these: Two aspects only marginally discussed in the recent literature. Readers interested in other aspects of research in subterranean biology are referred to the classic review on biomonitoring (Culver \& Sket, 2002) and published syntheses on sampling approaches (Dole-Olivier et al., 2009; Lunghi, Corti, et al., 2020; Oliveira et al., 2019; Weinstein \& Slaney, 1995; Wynne et al., 2018, 2019), species distribution modeling (Mammola \& Leroy, 2018), and best practices in experimental trials with subterranean organisms (Di Lorenzo et al., 2019). Sampling techniques in non cave subterranean habitats (Box 1 ) have also been reviewed elsewherefor example, boreholes (Hancock \& Boulton, 2009), epikarst (Brancelj, 2004), subaquatic caves (Humphreys et al., 1999; Iliffe, 2018; Iliffe \& Bowen, 2001), Milieu Souterrain Superficiel (Mammola et al., 2016), hyporheic (Fraser \& Williams, 1997), and interstitial habitats in coastal marine and lotic environments (Schmidt-Rhaesa, 2020). 


\section{3 | CHALLENGES TO SUBTERRANEAN RESEARCH}

\section{1 | Habitat impediment}

Whereas different habitats have been categorized as subterranean (Box 1), most in-field research takes place in caves, mines, and other human-accessible voids (Mammola, 2019). These are always dark, often muddy and humid, and sometimes even very cold, hence not offering favorable conditions to perform extensive, standardized observations (MacNeil \& Brcic, 2017). There are often high ceilings, narrow fissures, and other geomorphological features that hamper the task of approaching and observing target animals without them being disturbed by light or by the presence of the researcher $\left(\mathrm{CO}_{2}\right.$, heat, vibrations, or even diver's bubbles in the case of submerged passages). Furthermore, cave exploration requires well-trained researchers mastering the use of speleological equipment (Zagmajster et al., 2010). Even more challenging, in this sense, are those studies set in submerged passages of freshwater and marine caves (Exley, 1983; lliffe \& Bowen, 2001), as testified by the frequent fatalities associated with cave diving (Buzzacott et al., 2009).

Given our human size, we can directly access only a small fraction of the habitats available to the subterranean fauna. As noted by Howarth (1983) (p. 380), this is a significant obstacle to scientific research because, more often than not, we cannot directly inspect the extended network of fissures "[...] where probably the major drama in the cave ecosystem occurs". In a way, caves and other humanaccessible habitats may act as surrogates of the subterranean world in its entirety, windows allowing us to glimpse what usually happens away from human sight (Mammola et al., 2016; Polak, 1997; Uéno, 1987; Wilkens et al., 1986). Yet, in this case the existence of a habitat bias should be clearly acknowledged. For instance, we must be aware that the foraging behavior of a centipede that we have observed in a large chamber of a cave may not replicate in the same way-or may not even take place at all!-when the exact same centipede is dwelling in the millimetric fissures connected with the chamber. Not to mention certain typically benthic aquatic animals that have been spotted in the water column of flooded caves only after the disturbance produced by the divers (Humphreys et al., 1999).

As a corollary, however, it must be noted that a number of organisms primarily belong to human-accessible cavities (Moseley, 2009) and ipso facto are more readily studied (Mammola, 2019). Classic examples are vertebrates with a centimetric body size, such as different species of cave-roosting bats and groundwater fishes, but also the parasites and commensals associated with them (Lunghi, Ficetola, et al., 2018) or the scavengers that feed upon their carcasses and feces (Ferreira \& Martins, 1999). There are also subterranean invertebrates constrained to human-sized voids by their extended phenotypes; notably, different species of orb spiders needing larger voids for web construction (Mammola \& Isaia, 2017) or aquatic suspension feeders adapted to drift in the still water column of anchialine caves (Koenemann et al., 2007; Martínez et al., 2017).
Finally, in specific subterranean systems, there may be health risks related to biological diseases or toxic gases, potentially hampering or complicating explorations and studies. Examples include fungi [Histoplasma capsulatum (Eurotiomycetes: Ajellomycetaceae) causing histoplasmosis; Hunt et al., 1984; Diaz, 2018; Staffolani et al., 2018], and viruses, such as Marburg virus associated with fruit bats roosting in caves (Kuzmin et al., 2010) and the potential presence of SARS-CoV-2 coronavirus in touristic caves (Barton, 2020). Furthermore, cave-roosting bats may be vectors of rabies and a number of other emerging diseases (Calisher et al., 2006; Kuzmin et al., 2011)-amidst the COVID-19 pandemic in 2020, these potential zoonotic health risks have unfortunately resulted in persecutions of bats (MacFarlane \& Rocha, 2020; Rocha et al., 2020). Another human health threat may come from contaminated air due to the accumulation of hazardous gases including $\mathrm{CO}, \mathrm{CO}_{2}$, and sulfur exhalations. Also, the concentration of radon (a radioactive gas) may be elevated in the subterranean realm (Cigna, 2005; Gillmore et al., 2000)-in certain caves its levels can exceed recommended doses 20 -fold.

\section{2 | Biological impediment}

In several cases, the biology of subterranean species represents a further impediment to research. In general, food-deprived subterranean environments select for long-lived species with low metabolism and small numbers of offspring. As a consequence, the density of individuals of subterranean adapted species is often low-it is not unusual that such species were observed once at the time of their description, and never recorded thereafter (Delić \& Sket, 2015; Manenti et al., 2018; Martínez et al., 2013). Also, specialized subterranean species are often unevenly distributed in space and time, mostly because they aggregate around the scarce and heterogeneously distributed food sources (Culver \& Sket, 2002). These difficulties in finding sufficient individuals for experiments or in situ observations may result in studies with a reduced sample size and less robust data. This may explain why the ecology and behavior of many subterranean organisms is documented, at best, anecdotally thanks to casual observations.

Furthermore, many specialized subterranean organisms live in environments showing constant and buffered conditions and, over evolutionary time, have reduced their resilience against environmental fluctuations. For example, some terrestrial subterranean species are threatened by the smallest variations in air moisture content (Howarth, 1983), whereas aquatic animals may perish upon changes in pH driven by the water exposure to the air (Carpenter, 1999). Similarly, many terrestrial and aquatic obligate subterranean species survive only within narrow temperature ranges (Mammola, Piano, et al., 2019; Mermillod-Blondin et al., 2013; Pallarés, Colado, et al., 2020; Pallarés, Sanchez-Hernandez, et al., 2020). This limited physiological plasticity may pose a real challenge when a researcher is aiming to conduct experiments in the unnatural conditions of a typical laboratory. Maintaining living individuals of most of these animals is not a trivial 
task: breeding them requires skill and experience, in-depth knowledge of their biology and, often, none negligible doses of luck.

In some cases, an additional impediment may be our lack of knowledge on the taxonomy of subterranean organisms (e.g., Asmyhr \& Cooper, 2012; Camacho et al., 2018). This impediment (also known as 'Linnean shortfall'; Hortal et al., 2015) is especially problematic in studies focusing on community structure and functioning. It is particularly severe for tropical areas, whose subterranean fauna were largely unknown until very recently (e.g., Alvarenga et al., 2021; Trajano \& Bichuette, 2010; Trajano et al., 2016), as well as for certain small-sized animal groups which have been traditionally neglected despite being relatively abundant in subterranean habitats, such as diplurans (Sendra, Antić, et al., 2020; Sendra, Palero, et al., 2020), proturans (Galli et al., 2021), palpigrades (Mammola et al., 2021), nematodes (Du Preez et al., 2017), gastrotrichs (Kolicka et al., 2017), and other meiofaunal lineages (Martínez et al., 2019; Sánchez \& Martínez, 2019). The lack of taxonomists for many groups surely hampers the conduction of more concise studies on cave communities in many regions; a situation that is further aggravated by the existence of often high cryptic diversity within most subterranean taxa (Delić et al., 2017; Eme et al., 2018; Esposito et al., 2015; Fišer et al., 2018; Gonzalez et al., 2017; Niemiller et al., 2012).

\section{4 | EXPERIMENTAL SETUPS}

The most classical and intuitive way to learn about subterranean organisms lies in quantitative observational studies, either in the field (in situ), under laboratory conditions (ex situ) or, when available, in laboratories set within caves (here termed quasi in- situ). An experimental setup entirely based on simulations (in silico) could also be adopted. The choice among these setups is not always straightforward. In general, choosing between alternative options is a trade-off between the biological realism of the observations and either the ease or the extensiveness of the study (Figure 2). More detailed pros and cons of each setup are discussed in the following sections.

\section{1 | In situ}

The in-situ approach provides the least artefactual representation of the ecology, physiology, and behavior of the target species. Yet, this approach forces the researcher to comply with both the habitat (harsh working conditions and impossibility of exploring inaccessible habitats) and the biological (low density of most subterranean species) impediments. To minimize these impediments, a careful selection of the study site is critical. If possible, one should favor cavities with a linear development and reduced habitat complexity, thereby facilitating standardized observations (Lunghi, Corti, et al., 2020; Mammola \& Isaia, 2018; Smithers, 2005) while maximizing detectability of the animals (Lunghi, 2018). In the same vein, studying aquatic target species in a semi-submerged or shallow passageway not only increases permanence times and minimizes decompression procedures, but also maximizes safety (Iliffe, 2018).

It must be noted that in-situ studies can be carried out exclusively in cavities the researcher can enter herself or at least insert instruments into. There are different types of traps and sampling devices that allow us to indirectly collect the fauna in inaccessible and interstitial habitats or even tools for detecting the presence of a species indirectly (see section "Indirect means of research"). Conversely, in-situ observations are virtually impossible for porous groundwater, forcing researchers to heavily rely on laboratory studies (e.g., Di Lorenzo et al., 2014).

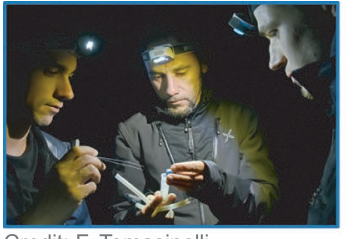

Credit: F. Tomasinelli

In-situ

e.g., monthly surveys of a cave species

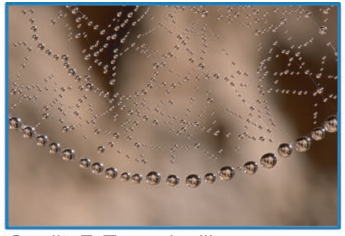

Credit: F. Tomasinelli

\section{In-situ (indirect)}

e.g., inference on diet using prey items in a spider web

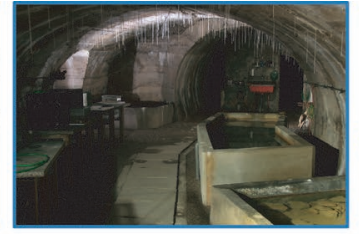

Credit: G. Aljančič

Quasi in-situ

e.g., ethological observation in a cave laboratory

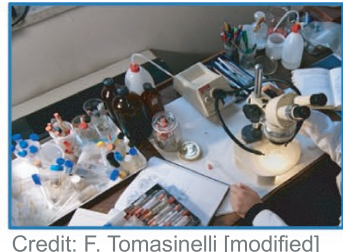

Ex-situ

.g., thermal tolerance test in a climatic chamber

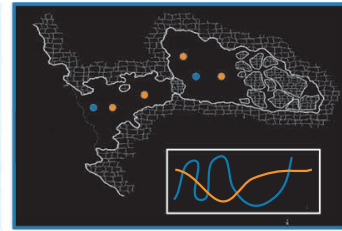

In-silico

e.g., agent based modelling of an hypothethical cave

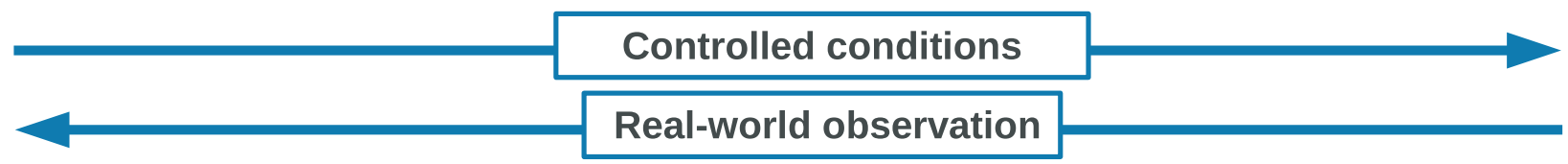

FIGURE 2 A theoretical trade-off between the ease of study and biological realism of the observations in different experimental setups. On the one hand, exploring a cave is physically demanding and requires specific speleological equipment, whereas it is possible to run a simulation sitting at home in front of a computer in a pyjama-and even during a COVID-19 pandemic! Running a simulation or conducting an experiment in the laboratory also allows us to control for a number of confounding factors. On the other hand, the result obtained in the field is often less artefactual, requiring no abstraction or formulation of a priori assumptions. At some point, when studying phenomena in the laboratory or with simulations, one will want to get back to the field to corroborate results using real-world observations 


\section{2 | Ex-situ}

The use of a meso- or microcosmos replicating the species' natural habitat allows us to bypass the habitat impediment in its entirety. In general, obtaining standardized observations in controlled conditions enhance a greater replicability of the results, and potentially allow researchers to perform long-lasting experiments and observations-see Carpenter (2021) for a recent example. Furthermore, ex-situ approaches permit to explore the life history of those animals that prefer inaccessible habitat, or that are too small to be observed with the naked eye. Yet, by choosing an exsitu approach, the researcher needs to comply with the biological impediment of maintaining specialized and delicate organisms in the laboratory (Di Lorenzo et al., 2019), as well as with the local conservation policies for endangered species. This can be circumvented by selecting certain model organisms, often not legally protected and relatively easy to keep in the laboratory (see section "Model organisms in subterranean biology").

As a drawback, laboratory observations may not accurately reflect the natural traits, especially behavioral and physiological, as shown in the cave (Silva et al., 2018). Although laboratory studies are useful, the ex-situ conditions rarely resemble those found in the natural habitat (e.g., higher density, different environmental conditions). For well-established model organisms, a prolonged ex-situ breeding may even produce unwelcome effects such as artificial selection or adaptation to the laboratory conditions (Ross et al., 2019). This is why observations obtained from studies in the laboratory must be carefully interpreted and preferably confirmed by in situ approaches (Blin et al., 2020). For example, by surveying seminatural replicas of the sheltered reproductive sites of Hydromantes salamanders (Amphibia: Plethodontidae) with infrared cameras, Oneto et al. (2010) were able to provide some of the first observational data on their complex reproductive behavior and parental care. Subsequent observations performed under natural conditions (Lunghi, Corti, et al., 2018; Lunghi et al., 2014, 2015) confirmed the validity of these observations.

\section{3 | Quasi in-situ}

The history of subterranean biology teaches us that a quasi in-situ approach-that is, to bring the laboratory into the target species natural habitat-eases many of the problems associated with experimental studies in the laboratory. Establishing an experimental facility within the cave itself not only spare living animals from long transportation away from the cave, but also facilitates fine-regulation of ambient parameters within a microcosmos. The most famous example is probably the Laboratoire Souterrain de Moulis (Centre national de la recherche scientifique; CNRS), a cave-based laboratory established in the French Pyrenees by René Jeannel (1879-1965) and Albert Vandel (1894-1980). Since its foundation in 1948, this semi-natural experimental setting has aided generations of subterranean biologists in the challenging task of shedding light on the natural history and behavior of a wide range of elusive subterranean life forms (Clergue-Gazeau, 1974; Durand, 1970; Juberthie, 1985; Juberthie et al., 1996; Manenti et al., 2020). For aquifers, the equivalent would be to lower sediment, substrate cages, bags into groundwater wells (Schmidt et al., 2004), which, however, would still have to be retrieved every time to study the organisms.

As a corollary, it must be noted that establishing an experimental facility inside a given cave may have a significant local impact in terms of destruction of certain microhabitats and/or alterations of the microclimate. Therefore, the establishment of similar infrastructures should be evaluated on a case-by-case basis and supported by an environmental risk assessment.

\section{4 | In-silico}

As a consequence of the habitat and biological impediments, studies in subterranean habitats often rely on data that is far from ideal. In a complex subterranean setting, we may lack information on environmental seasonal fluctuations, species abundances across space or time, their physiological rates and life-history traits, or the species they interact with. Not to mention the dependency between observations and the correlation among traits (body size and trophic guild, fecundity with longevity, etc.), which often confounds with putative drivers for the process that we aim to disentangle. In those scenarios, simulations, such as agent-based models and cellular automata, are increasingly used to explore the dynamics of natural ecosystems and trigger novel ideas for further exploration in real-world settings (DeAngelis \& Grimm, 2014). These mechanistic models rely on the socalled "first principles," such as energy budgets, physiology, or fitness seeking (Grimm \& Berger, 2016), which define the initial conditions of the simulation so that behavior and interactions emerge rather than being imposed by the modeler. Given robust enough assumptions, simulations are thus able to realistically replicate sets of empirical patterns without restricting them to a single deterministic scenario (Grimm et al., 2005). For example, the use of eco-evolutionary agentbased models, which include heritable traits and the use of genetic algorithms, provides insights on the evolution of certain morphological, physiological, and behavioral traits (Ayllón et al., 2018).

Surprisingly, however, simulations have rarely been applied in subterranean biology. Applications to subsurface systems so far have been restricted to porous groundwater, with the focus being mainly on contaminant degradation (Benioug et al., 2015, 2017; Schmidt et al., 2018; Tang et al., 2013), and to soils (e.g., Banitz et al., 2013; Borer et al., 2019; Kim \& Or, 2016). It is easy to see how the simulation of a virtual cave would be an interesting aid to research. Caves may represent ideal model systems for in-silico studies due to their constant environmental conditions, which can be easily and predictably simulated, and their simple community structure with few species and limited interactions. For example, these models would allow us to achieve a mechanistic understanding of the processes behind interactions between species within a typical subterranean community, to explore pathways of 
subterranean evolution, and even to elucidate the impact of climate change on subterranean biodiversity.

The applicability of these theoretical models to the real biological world, however, still depends on the quality and availability of data. Parametrization of simulations might be relatively simple for broad questions in spatial or temporal scope, but quite complex for very specific systems, often implying the need for possessing detailed information. Thus, and this is true for other methods as well, the necessity to parametrize theoretical models with the real-world biological observations may require combining simulation approaches with actual fieldwork. Importantly, models may single out those parameters that warrant the most attention and may thus steer experiments toward focussing on sensitive and critical parameters. A complementary avenue is combining qualitative observations, for example, that state changes are confined within a certain interval, for parameterization. Even if a single observation does not contain much information, a combination of several qualitative observations can be as distinctive as a single high-precision observation. This inverse, "pattern-oriented" parameterization (Grimm et al., 2005; Wiegand et al., 2004), has been proven to be a powerful approach and overlaps with the more formal approximate Bayesian computing approach (Hartig et al., 2011).

\section{5 | Indirect means of research}

A plethora of indirect methodologies can be used to overcome both the habitat and the biological impediments (Figure 1). These approaches are mostly species- and system-specific, and it is impossible to provide widely general recommendations. Therefore, we here discuss examples chosen to illustrate the concept of "indirect research."

Information about the ecology and behavior of large-sized animals can be acquired via infrared video surveillance. This represents a low-cost and low-personnel effort methodology, which has a long tradition in ethological research and biomonitoring (Swann et al., 2004). In caves, thermal-infrared imaging and laser scanning have been extensively applied to study the swarming and roosting behaviors of bats (Azmy et al., 2012; Elliott et al., 2005), but could potentially be used for other vertebrates, such as cave salamanders (Lunghi, Manenti, et al., 2020). In at least one case, camera trapping has even been used to quantifying wildlife use of cave entrances (Baker, 2015).

Recently, there has also been a great deal of discussion on the use of molecular tools to obtain indirect evidence of the presence and behavior of species, especially in difficult-to-access habitats, as well as to overcome prevalent taxonomic biases (Malard et al., 2020). For example, environmental DNA was successfully used to detect the presence of focal subterranean species, such as amphibians (Gorički et al., 2017) and crustaceans (Boyd et al., 2020; DiStefano et al., 2020; Niemiller et al., 2018). The analysis of gut or stomach content of species inhabiting both human-accessible and interstitial environments provides information on dietary requirements and trophic behaviors taking place in both these compartments
(Lunghi, Cianferoni, et al., 2018; Lunghi, Manenti, et al., 2020), but also trophic web studies with aquatic subterranean species (Saccò et al., 2019). These analyses can be done visually, but also through massive sequencing techniques, allowing the identification of the gut content using DNA (Rastorgueff et al., 2015). Similarly, stable isotopes proved useful to understand species interactions and niche partitioning (Chávez-Solís et al., 2020), as well as identifying potential carbon sources through space (Brankovits et al., 2017) and time (Saccò et al., 2020).

In some circumstances, the species' extended phenotype also informs indirectly on specific behaviors and ecological needs. The web in web-building spiders, for example, can be viewed as an extended phenotype that enlarges the sensory world of its builder in interaction with the environment (Blamires, 2010). The web also provides a record frozen in time of the spider's foraging behavior, as spiders modify their webs in response to a large range of biotic and abiotic stimuli, including previous prey experiences, climatic variables, and the structural complexity of the habitat (Hesselberg, 2015; Vollrath \& Selden, 2007). The easily quantifiable two-dimensional orb-web, in particular, is highly suitable for behavioral studies, as orb spiders can easily be maintained in the laboratory (Zschokke \& Herberstein, 2005) or their webs measured in the field (Hesselberg, 2010). The ubiquity of orb-web spiders near the entrance of temperate caves makes this approach especially promising (Hesselberg et al., 2019). Likewise, the calcified tubes of several hard-bodied aquatic organisms, such as tube-building polychaetes, bring us information on the evolution of aquatic caves communities and paleoclimate from past geological eras (Moldovan et al., 2011).

The living world has long been used as a source for developing biologically inspired robots using biomimetics design principles to provide innovative technical solutions (Lenau et al., 2018; Pfeifer et al., 2007; Vincent et al., 2006). In recent years, the use of biorobotic models to test and generate biological hypotheses has been gaining ground (Gravish \& Lauder, 2018). Following this recent trend, we propose that the use of small, agile biorobots to explore, record, and interact with subterranean animals in their natural habitats might overcome many of the habitat and biological impediments previously discussed (Woodward \& Sitti, 2014). For example, the use of a simple biomimetic robot fish has been successfully used to highlight similarities and differences in social behavior between surface and cave-dwelling populations of Poecilia mexicana (Actinopterygii: Poeciliidae) (Bierbach et al., 2018).

\section{5 | MODEL ORGANISMS IN SUBTERRANEAN BIOLOGY}

Model organisms represent only a small part of Earth's biodiversity and yet have largely contributed to our knowledge on many fields within the biological sciences (Hedges, 2002). The earliest models, such as flies, mice, or roundworms, were selected for the task simply because they were small, proliferative, and easy to culture and manipulate; they were, however, quite limiting in advancing many 
aspects in ecology and evolution. Luckily, the growth of modern molecular methods, staining and imaging techniques, and gene editing, have facilitated choosing more appropriate models for the biological question at hand rather than enforcing the ones that can be easily grown and manipulated (Müller \& Grossniklaus, 2010). Consequently, the number of model species has diversified along with the number scientific questions, and now includes representatives of many animal phyla (as well as plants and fungi). This exciting transition in contemporary biology is embodied by the term "nonmodel" organism, which reflects that the diversity of model species has grown nearly parallel with the diversity of problems addressed (Goldstein \& King, 2016; Russell et al., 2017; Sullivan, 2015).

The trend of diversification of model systems and research question is evident in cave biology as well. To comprehend it, we have compiled a list of those subterranean animals that can be considered as model organisms (Table S1). We selected models based on two criteria: (a) organisms/groups with accumulated at least 20 papers in the Web of Science (accessed on 25 November 2020); and (b) organisms/groups with at least two independent research laboratories focusing on them. Our list of model organisms includes species with different degrees of subterranean specialization across three phyla, but it is dominated by Teleostei fish and Crustacea (Figure 3). This reflects the traditional research bias in subterranean biology toward these groups, only partially justified by their dominance across subterranean environments. Only a few of these species satisfy the traditional requirement of a model-successful culturing in the lab and keeping long-standing laboratory breeds [e.g., Astyanax mexicanus (Actinopterygii: Characidae), Asellus aquaticus (Isopoda: Asellidae), and Poecillia mexicana]. By far, the most famous and studied among these is the cavefish Astyanax mexicanus (Jeffery, 2020; Keene et al., 2016; Torres-Paz et al., 2018), which has been kept in captivity for many generations (Wilkens, 1971) and is increasingly used and recognized as suitable for tackling problems beyond the typical subterranean biology realm (Maher, 2009; McGaugh et al., 2020). Other models thrive in laboratory conditions, but are unable to complete their life cycle therein [e.g., Gammarus minus (Amphipoda: Gammaridae), Australian calcrete Dytiscidae insects]. Most models in subterranean biology are lineages with both surface and subterranean populations, or species whose populations exhibit different degrees of subterranean specialization. Among those, Astyanax mexicanus and Asellus aquaticus are even able to form hybrid offspring between cave and surface morphs in laboratory conditions (Jeffery, 2020; Protas \& Jeffery, 2012).

Alongside every other biological discipline, cave biology research has entered the genomics era (Friedrich, 2013; Pérez-Moreno et al., 2016). Already half of cave models listed in Table S1 have been included in genome (transcriptome) sequencing projects, becoming windows into the molecular basis of adaptation (Barbosa et al., 2017; Berning et al., 2019). With the decreasing prices and the development of more user friendly bioinformatic recourses, so-called-omics tools will soon be at the forefront of cave research and exploited in the remaining model systems. Such tools may enable overcoming traditional restrictions on the use of subterranean species as models and we predict that the peculiar, and even bizarre, traits of subterranean animals are going to draw attention from an increasingly wider audience, and possibly attract new researchers into the field (Mammola et al., 2020).

In subterranean biology, the concept of model organism has also been applied to supra-specific lineages widely used to investigate evolutionary processes associated with cave colonization or to answer biogeographic and macroecological questions. Similar studies typically rely on comparative methods within explicit phylogenetic frameworks, allowing us to distinguish the role played by ecological adaptations and evolutionary history on the observed ecological and distribution patterns (Juan et al., 2010; Mammola et al., 2020). Some of these models account for lineages including both surface and subterranean species exhibiting different degrees of adaptations and ecological preferences, such as Asellus (Verovnik et al., 2004), Niphargus (Amphipoda: Niphargidae) (Fišer, 2009), Trechus (Coleoptera: Carabidae) (Möst et al., 2020), and Dysdera (Araneae: Dysderidae) (Arnedo et al., 2007). Others exclusively consist of subterranean species, such as atyd shrimps (Decapoda: Atyidae) of the genera Typhlatya, Stygiocaris, Speleocaris, and Troglocaris (Jurado-Rivera et al., 2017; Zakšek et al., 2009). While lineages in the first group are useful to understand different mechanisms for ecological speciation and habitat shift, subterranean-exclusive lineages allow us to understand the role of historical stochastic processes in subterranean diversity and biogeography (Juan et al., 2010). In addition, subterranean-exclusive lineages have been studied in comparison with distantly surface-dwelling relatives to understand the adaptation processes related to the colonization of the subterranean environment [e.g., Phreatichthys andruzzii (Actinopterygii: Cyprinidae)]. Although intuitively less ideal, this approach has yielded some important insights, such as the impacts of life in darkness on the circadian clock or DNA repair mechanisms (Cavallari et al., 2011).

Finally, some subterranean species with unique features have been established as models to investigate scientific questions not necessarily related to the classic subterranean research agenda. This is the case of the carnivorous sponge Lycopodina hypogea (Demospongiae: Cladorhizidae), used as a model for early nervous system evolution and developmental biology (Godefroy

FIGURE 3 Diversity of model organisms in subterranean biology across the animal Tree of Life. The branch Cambaridae refers to the genera Cambarus, Orconectes, Procambarus, and Troglocambarus. Atyidae refers to the exclusively subterranean genera Speleocaris, Stygiocaris, Troglocaris, and Typhlatya. Dytiscidae indicates the Australian diving beetles of the genera Limbodesus, Nirridesus, Nirripirti, and Paroster. Amblyopsidae indicates the North American cave fish in the genera Amblyopsis, Chologaster, Forbesichthys, Speleoplatyrhinus, and Typhichthys. WoS entries: Number of papers focusing on the species in Web of Science (accessed on 25 November 2020). (1-3): The information refers to the genera (1) Speleocaris, Stygiocaris, Troglocaris, and Typhlatya; (2) Cambarus, Orconectes, Procambarus, and Troglocambarus; (3) Paroster, Limbodesus, Nirridesus, and Nirripirti 


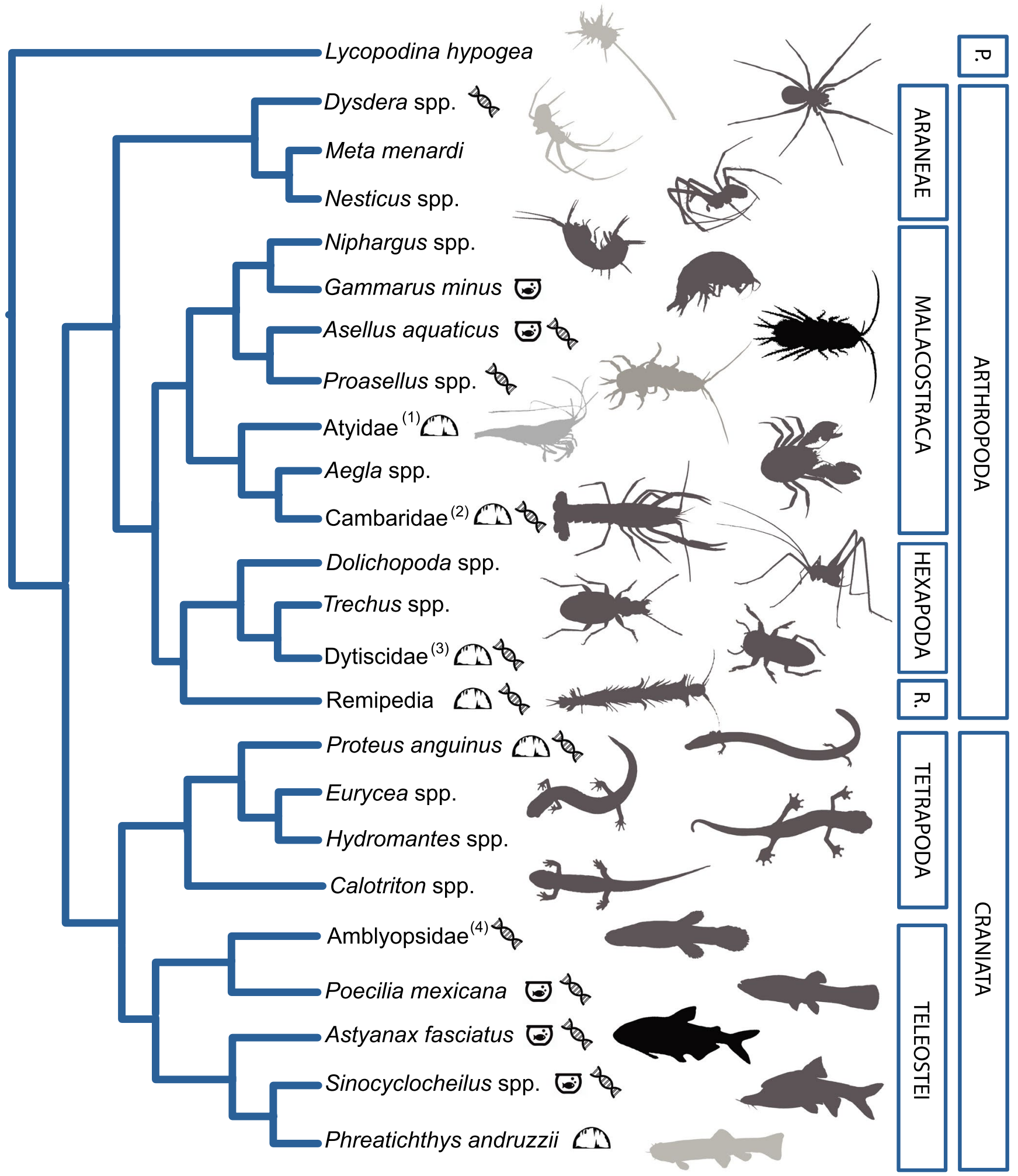

$>1000$ WoS entries

4 Transcriptome/Genome
50-1000 WoS entries

Established lab cultures
20-50 WoS entries

DD. Exclusively subterranean 
et al., 2019); the crustaceans in the class Remipedia, key to understanding the evolution of terrestrial arthropods (Lozano-Fernandez et al., 2016), the evolution of the nervous system (Stemme et al., 2013), and venoms toxins (von Reumont et al., 2014); or the "forever young" aquatic salamander Proteus anguinus (Amphibia: Proteidae), whose progenetic origin and long lifespan has triggered fruitful research on the molecular mechanisms of aging (Voituron et al., 2011). Also, A. mexicanus have been increasingly used as a model organism in various areas of biomedical research, such as diabetes (Riddle et al., 2018), insomnia (Jaggard et al., 2018), autism (Yoshizawa et al., 2018), and regeneration (Stockdale et al., 2018). While those are not the questions that have inspired most cavebased researchers over the years, they have recently attracted considerable interest and funding, thereby illustrating the general idea of our review here: Caves, in their uniqueness for humans, still hold the secrets for understanding broad scientific questions (Martínez \& Mammola, 2020).

\section{6 | CONCLUSIONS}

In this work, we discussed best practices and novel ideas for performing standardized research in subterranean ecosystems, by focusing on key impediments, experimental ideas, and model systems. The main take-home messages that emerge from this exercise are as follows:

1. Be aware of the many options out there. Insofar as each subterranean system and organism is unique to some extent, and in light of the impediments to subterranean research, scientists must be creative in designing their experiments. Research in subterranean biology often implies combining traditional in situ field observations with standardized studies in a laboratory setting, either within a cave (quasi in-situ) or outside the cave (ex-situ). It is also important to be aware of the potential of novel tools, especially simulations, artificial intelligence methods, and biorobotics (Figure 1).

2. Choose the right model. Many impediments to subterranean research can be overcome by focusing on model organisms, which have been established owing to their specific traits and/or their broad availability in subterranean environments. Whereas model systems in subterranean biology are probably not as developed as in other disciplines, there are options across the animal tree of life offering great potential for tackling specific research questions (Figure 3). Since a major challenge before fully exploiting a given model is to breed it in the laboratory, it would be worthwhile endeavor to run a wider screening among candidate organisms. In this way, a model suitable to answer a given set of questions and able to complete its lifecycle in the laboratory can be identified.

3. Be aware of the taxonomic bias. As a corollary of the previous point, it is important to remember that our knowledge of subterranean species is still strongly biased in its taxonomical coverage. Even today, the natural history information on subterranean species remains largely fragmented, rarely standardized, and often biased toward a few well-studied model organisms and temperate regions. We stress the importance of broadening eco-evolutionary studies to incorporate a larger range of organisms and subterranean habitats, to explore hypotheses about the emergence of convergent traits and behaviors across distant taxa while accounting for phylogenetic effects.

4. Embrace multidisciplinarity. In light of the habitat and biological impediments, combining ecological and behavioral observations with evolutionary approaches, genetic tools, and simulations are a critical premise. In the -omics era, integrative studies are expected to grow, allowing us to understand which molecular adjustments (including epigenetic effects) occur during the surface-subterranean transitions. This is required, for example, to disentangle the role of standing genetic variation and phenotypic plasticity in driving the evolution of subterranean populations (Bilandžija et al., 2020).

\section{ACKNOWLEDGMENTS}

We are grateful to Gregor Aljančič, Francesco Tomasinelli, and Marco Isaia for sharing with us the photographs used in Figure 2. Melissa B. Meierhofer provided useful information on bat diseases. SM is supported by the CAWEB project "Testing macroecological theory using simplified systems," funded by the European Commission through Horizon 2020 Marie Skłodowska-Curie Actions (MSCA) individual fellowship (grant no. 882221). EL is supported by the Chinese Academy of Sciences President's International Fellowship Initiative for postdoctoral researchers. HB is funded by the Tenure Track Pilot Programme of the Croatian Science Foundation and the Ecole Polytechnique Fédérale de Lausanne and the Project TTP-2018-07-9675 EvoDark with funds of the Croatian-Swiss Research Programme. SIS acknowledges funding by the Ministry of Education, Youth and Sports of the Czech Republic (grant number LM2015075, EF16 013/0001782, and CZ.02.1.01/0.0/0.0/16 025/0007417).

\section{CONFLICTS OF INTEREST}

None declared.

\section{AUTHORS CONTRIBUTION}

SM wrote the first draft. AM and SIS provided most arguments on aquatic habitats. EL and HB provided most arguments on vertebrates. AM, SM, and HB developed the section on model organisms. PC, SIS, and VG developed the in silico section. TH provided expert opinion on different sections, especially on behavioral topics. AM and SM prepared figures. All authors contributed to the writing with comments and additions.

\section{DATA AVAILABILITY STATEMENT}

This review contains no data. Number of papers and molecular sequences included in Table S1 have been derived from Web of Science and GeneBank (accessed on 5 January 2021). 


\section{ORCID}

Stefano Mammola iD https://orcid.org/0000-0002-4471-9055

Enrico Lunghi (iD https://orcid.org/0000-0002-4228-2750

Pedro Cardoso (iD https://orcid.org/0000-0001-8119-9960

Volker Grimm (iD https://orcid.org/0000-0002-3221-9512

Thomas Hesselberg (iD https://orcid.org/0000-0002-9735-2488

Alejandro Martínez iD https://orcid.org/0000-0003-0073-3688

\section{REFERENCES}

Alvarenga, D., Silva, M., \& Ferreira, R. (2021). Trogloregions: Delimiting subterranean faunistic identities in Afrotropics and Neotropics. Nature Portfolio, https://doi.org/10.21203/rs.3.rs-53597/v1

Arnedo, M. A., Oromí, P., Múrria, C., Macías-Hernández, N., \& Ribera, C. (2007). The dark side of an island radiation: Systematics and evolution of troglobitic spiders of the genus Dysdera Latreille (Araneae:Dysderidae) in the Canary Islands. Invertebrate Systematics, 21(6), 623-660. https://doi.org/10.1071/IS07015

Asmyhr, M. G., \& Cooper, S. J. B. (2012). Difficulties barcoding in the dark: The case of crustacean stygofauna from eastern Australia. Invertebrate Systematics, 26(6), 583-591. https://doi.org/10.1071/ IS12032

Ayllón, D., Railsback, S. F., Almodóvar, A., Nicola, G. G., Vincenzi, S., Elvira, B., \& Grimm, V. (2018). Eco-evolutionary responses to recreational fishing under different harvest regulations. Ecology and Evolution, 8(19), 9600-9613. https://doi.org/10.1002/ece3.4270

Azmy, S. N., Sah, S. A. M., Shafie, N. J., Ariffin, A., Majid, Z., Ismail, M. N. A., \& Shamsir, M. S. (2012). Counting in the dark: Non-intrusive laser scanning for population counting and identifying roosting bats. Scientific Reports, 2, 524. https://doi.org/10.1038/srep00524

Baker, G. M. (2015). Quantifying wildlife use of cave entrances using remote camera traps. Journal of Cave and Karst Studies, 77, 200-210. https://doi.org/10.4311/2015ES0101

Banitz, T., Johst, K., Wick, L. Y., Schamfuß, S., Harms, H., \& Frank, K. (2013). Highways versus pipelines: Contributions of two fungal transport mechanisms to efficient bioremediation. Environmental Microbiology Reports, 5(2), 211-218. https://doi. org/10.1111/1758-2229.12002

Barbosa, P., Leal, E. V., da Silva, M., de Almeida, M. C., Moreira-Filho, O., \& Artoni, R. F. (2017). Variability and evolutionary implications of repetitive DNA dynamics in genome of Astyanax scabripinnis (Teleostei, Characidae). Comparative Cytogenetics, 11(1), 143-162. https://doi.org/10.3897/CompCytogen.v11i1.11149

Barton, H. A. (2020). Safe and effective disinfection of show cave infrastructure in a time of COVID-19. International Journal of Speleology, 49, 137-147. https://doi.org/10.5038/1827-806X.49.2.2332

Benioug, M., Golfier, F., Oltéan, C., Buès, M. A., Bahar, T., \& Cuny, J. (2017). An immersed boundary-lattice Boltzmann model for biofilm growth in porous media. Advances in Water Resources, 107, 65-82. https://doi.org/10.1016/j.advwatres.2017.06.009

Benioug, M., Golfier, F., Tinet, A.-J., Buès, M. A., \& Oltéan, C. (2015). Numerical efficiency assessment of IB-LB method for 3D pore-scale modeling of flow and transport. Transport in Porous Media, 109(1), 123. https://doi.org/10.1007/s11242-015-0497-6

Berning, D., Adams, H., Luc, H., \& Gross, J. B. (2019). In-frame indel mutations in the genome of the blind Mexican cavefish, Astyanax mexicanus. Genome Biology and Evolution, 11(9), 2563-2573. https://doi. org/10.1093/gbe/evz180

Bierbach, D., Lukas, J., Bergmann, A., Elsner, K., Höhne, L., Weber, C., Weimar, N., Arias-Rodriguez, L., Mönck, H. J., Nguyen, H., Romanczuk, P., Landgraf, T., \& Krause, J. (2018). Insights into the social behavior of surface and Cave-Dwelling Fish (Poecilia mexicana) in light and darkness through the use of a Biomimetic robot. Frontiers Robotics Al, 5, 3. https://doi.org/10.3389/frobt.2018.00003
Bilandžija, H., Hollifield, B., Steck, M., Meng, G., Ng, M., Koch, A. D., Gračan, R., Ćetković, H., Porter, M. L., Renner, K. J., \& Jeffery, W. (2020). Phenotypic plasticity as a mechanism of cave colonization and adaptation. Elife, 9, e51830. https://doi.org/10.7554/eLife.51830

Blamires, S. J. (2010). Plasticity in extended phenotypes: Orb web architectural responses to variations in prey parameters. Journal of Experimental Biology, 213, 3207-3212. https://doi.org/10.1242/ jeb.045583

Blin, M., Fumey, J., Lejeune, C., Policarpo, M., Leclercq, J., Père, S., Torres-Paz, J., Pierre, C., Imarazene, B., \& Rétaux, S. (2020). Diversity of olfactory responses and skills in Astyanax mexicanus cavefish populations inhabiting different caves. Diversity, 12, 395. https://doi. org/10.3390/d12100395

Borer, B., Ataman, M., Hatzimanikatis, V., \& Or, D. (2019). Modeling metabolic networks of individual bacterial agents in heterogeneous and dynamic soil habitats (IndiMeSH). PLoS Computational Biology, 15(6), e1007127. https://doi.org/10.1371/journal.pcbi.1007127

Boyd, S. H., Niemiller, K. D. K., Dooley, K. E., Nix, J., \& Niemiller, M. L. (2020). Using environmental DNA methods to survey for rare groundwater fauna: Detection of an endangered endemic cave crayfish in northern Alabama. PLoS One, 15(12), e0242741. https://doi. org/10.1371/journal.pone.0242741

Brancelj, A. (2004). Biological sampling methods for epikarst water. In W. K. Jones, D. C. Culver, \& J. S. Herman (Eds.), Epikarst (pp. 99-103). Karst Waters Inst. Special Publ.

Brankovits, D., Pohlman, J. W., Niemann, H., Leigh, M. B., Leewis, M. C., Becker, K. W., lliffe, T. M., Alvarez, F., Lehmann, M. F., \& Phillips, B. (2017). Methane-and dissolved organic carbon-fueled microbial loop supports a tropical subterranean estuary ecosystem. Nature Communications, 8(1), 1-12. https://doi.org/10.1038/s41467-01701776-x

Buzzacott, P. L., Zeigler, E., Denoble, P., \& Vann, R. (2009). American cave diving fatalities 1969-2007. International Journal of Aquatic Research and Education, 3, 162-177. https://doi.org/10.25035/ijare.03.02.07

Calisher, C. H., Childs, J. E., Field, H. E., Holmes, K. V., \& Schountz, T. (2006). Bats: Important reservoir hosts of emerging viruses. Clinical Microbiology Reviews, 19(3), 531-545. https://doi.org/10.1128/ CMR.00017-06

Camacho, A. I., Mas-Peinado, P., Dorda, B. A., Casado, A., Brancelj, A., Knight, L. R. F. D., Hutchins, B., Bou, C., Perina, G., \& Rey, I. (2018). Molecular tools unveil an underestimated diversity in a stygofauna family: A preliminary world phylogeny and an updated morphology of Bathynellidae (Crustacea: Bathynellacea). Zoological Journal of the Linnean Society, 183(1), 70-96. https://doi.org/10.1093/zoolinnean/ zlx063

Carpenter, J. H. (1999). Behavior and ecology of Speleonectes epilimnius (Remipedia, Speleonectidae) from surface water of an anchialine cave on San Salvador Island. Bahamas. Crustaceana, 72(8), 979-991. https://doi.org/10.1163/156854099503889

Carpenter, J. H. (2021). Forty-year natural history study of Bahalana geracei Carpenter, 1981, an anchialine cave-dwelling isopod (Crustacea, Isopoda, Cirolanidae) from San Salvador Island, Bahamas: Reproduction, growth, longevity, and population structure. Subterranean Biology, 37, 105-156. https://doi.org/10.3897/subtbiol.37.60653

Cavallari, N., Frigato, E., Vallone, D., Fröhlich, N., Lopez-Olmeda, J. F., Foà, A., Berti, R., Sánchez-Vázquez, F. J., Bertolucci, C., \& Foulkes, N. S. (2011). A blind circadian clock in cavefish reveals that opsins mediate peripheral clock photoreception. PLoS Biology, 9(9), e1001142. https://doi.org/10.1371/journal.pbio.1001142

Chávez-Solís, E. M., Solís, C., Simões, N., \& Mascaró, M. (2020). Distribution patterns, carbon sources and niche partitioning in cave shrimps (Atyidae: Typhlatya). Scientific Reports, 10(1), 1-16. https:// doi.org/10.1038/s41598-020-69562-2

Cigna, A. A. (2005). Radon in caves. International Journal of Speleology, 34, 1-18. https://doi.org/10.5038/1827-806X.34.1.1 
Clergue-Gazeau, M. (1974). Reproduction des Urodèles: Perturbation du cycle sexuel des Euproctes males en élevage à la Grotte de Moulis. Memoires De Biospeologie, 29, 137-141.

Culver, D. C., \& Pipan, T. (2014). Shallow subterranean habitats: Ecology, evolution, and convervation. Oxford University Press. https://doi. org/10.4311/2014br0127

Culver, D. C., \& Pipan, T. (2019). The biology of caves and other subterranean habitats (2nd ed.). Oxford University Press.

Culver, D. C., \& Sket, B. (2002). Biological monitoring in caves. Acta Carsologica, 31, 55-64. https://doi.org/10.3986/ac.v31i1.403

da Silva, A. P. B., Oliveira, I. P. M. R., Bastos-Pereira, R., \& Ferreira, R. L. (2018). Are laboratory studies on behavior of troglobitic species always trustful? A case study with an isopod from Brazil. Behavioural Processes, 153, 55-65. https://doi.org/10.1016/j. beproc.2018.05.009

DeAngelis, D. L., \& Grimm, V. (2014). Individual-based models in ecology after four decades. F1000Prime Reports, 6, 39. https://doi. org/10.12703/P6-39

Delić, T., \& Sket, B. (2015). Found after 60 years: The hows and whys of Sphaeromides virei montenigrina (Crustacea: Isopoda: Cirolanidae) rediscovery in Obodska pećina, Montenegro. Natura Sloveniae, 17, 59-65.

Delić, T., Trontelj, P., Rendoš, M., \& Fišer, C. (2017). The importance of naming cryptic species and the conservation of endemic subterranean amphipods. Scientific Reports, 7(1), 3391. https://doi. org/10.1038/s41598-017-02938-z

Di Lorenzo, T., Di Marzio, W. D., Fiasca, B., Galassi, D. M. P., Korbel, K., lepure, S., Pereira, J. L., Reboleira, A. S. P. S., Schmidt, S. I., \& Hose, G. C. (2019). Recommendations for ecotoxicity testing with stygobiotic species in the framework of groundwater environmental risk assessment. Science of the Total Environment, 681, 292-304. https:// doi.org/10.1016/J.SCITOTENV.2019.05.030

Di Lorenzo, T., Di Marzio, W. D., Sáenz, M. E., Baratti, M., Dedonno, A. A., Iannucci, A., Cannicci, S., Messana, G., \& Galassi, D. M. P. (2014). Sensitivity of hypogean and epigean freshwater copepods to agricultural pollutants. Environmental Science and Pollution Research, 21, 4643-4655. https://doi.org/10.1007/s11356-013-2390-6

Diaz, J. H. (2018). Environmental and wilderness-related risk factors for histoplasmosis: More than bats in caves. Wilderness \& Environmental Medicine, 29(4), 531-540. https://doi.org/10.1016/j. wem.2018.06.008

DiStefano, R. J., Ashley, D., Brewer, S. K., Mouser, J. B., \& Niemiller, M. (2020). Preliminary investigation of the critically imperiled Caney Mountain cave crayfish Orconectes stygocaneyi (Hobbs III, 2001) (Decapoda: Cambaridae) in Missouri, USA. Freshwater Crayfish, 25, 47-57. https://doi.org/10.5869/fc.2020.v25-1.047

Dole-olivier, M.-J., Castellarini, F., Coineau, N., Galassi, D. M. P., Martin, P., Mori, N., Valdecasas, A., \& Gibert, J. (2009). Towards an optimal sampling strategy to assess groundwater biodiversity: Comparison across six European regions. Freshwater Biology, 54, 777-796. https:// doi.org/10.1111/j.1365-2427.2008.02133.x

Du Preez, G., Majdi, N., Swart, A., Traunspurger, W., \& Fourie, H. (2017). Nematodes in caves: A historical perspective on their occurrence, distribution and ecological relevance. Nematology, 19, 627-644. https://doi.org/10.1163/15685411-00003068

Durand, P. J. (1970). Fortpflanzung und Entwicklung von Hydromantes, dem Höhlenmolch. Aqua Terra, 7, 42-48.

Elliott, R. W., Kaufmann, J. E., Samoray, S. T., \& Gardner, S. E. (2005). The MDC method: Counting bats with infrared video. In G. T. Rea (Ed.), Proceedings of the 2005 National Cave and Karst management symposium (pp. 147-153). The NCKMS Steering Committee.

Eme, D., Zagmajster, M., Delić, T., Fišer, C., Flot, J.-F., Konecny-Dupré, L., Pálsson, S., Stoch, F., Zakšek, V., Douady, C. J., \& Malard, F (2018). Do cryptic species matter in macroecology? Sequencing European groundwater crustaceans yields smaller ranges but does not challenge biodiversity determinants. Ecography, 41(2), 424-436. https://doi.org/10.1111/ecog.02683

Esposito, L. A., Bloom, T., Caicedo-Quiroga, L., Alicea-Serrano, A. M., Sánchez-Ruíz, J. A., May-Collado, L. J., Binford, G. J., \& Agnarsson, I. (2015). Islands within islands: Diversification of tailless whip spiders (Amblypygi, Phrynus) in Caribbean caves. Molecular Phylogenetics and Evolution, 93, 107-117. https://doi.org/10.1016/J. YMPEV.2015.07.005

Exley, S. (1983). Lanzarote volcanic cave expedition 1983. Explorers Journal, 118-123.

Ferreira, R. L., \& Martins, R. P. (1999). Trophic structure and natural history of bat guano invertebrate communities, with special reference to Brazilian caves. Tropical Zoology, 12, 231-252. https://doi. org/10.1080/03946975.1999.10539391

Ficetola, G. F., Canedoli, C., \& Stoch, F. (2019). The Racovitzan impediment and the hidden biodiversity of unexplored environments. Conservation Biology, 33(1), 214-216. https://doi.org/10.1111/ cobi.13179

Fišer, C. (2009). Niphargus-A model system for evolution and ecology. In D. C. Culver \& W. B. White (Eds.), Encyclopedia of caves (pp. 746755). Academic Press.

Fišer, C., Pipan, T., \& Culver, D. C. (2014). The vertical extent of groundwater metazoans: An ecological and evolutionary perspective. BioScience, 64(11), 971-979. https://doi.org/10.1093/biosci/biu148

Fišer, C., Robinson, C. T., \& Malard, F. (2018). Cryptic species as a window into the paradigm shift of the species concept. Molecular Ecology, 27(3), 613-635. https://doi.org/10.1111/mec.14486

Fraser, B. G., \& Williams, D. D. (1997). Accuracy and precision in sampling hyporheic fauna. Canadian Journal of Fisheries and Aquatic Sciences, 54(5), 1135-1141. https://doi.org/10.1139/f97-024

Friedrich, M. (2013). Biological clocks and visual systems in caveadapted animals at the dawn of speleogenomics. Integrative and Comparative Biology, 53(1), 50-67. https://doi.org/10.1093/icb/ ict058

Galli, L., Janžekovič, F., Kozel, P., \& Novak, T. (2021). Protura (Arthropoda: Hexapoda) in Slovenian caves. International Journal of Speleology, 50, 65-74. https://doi.org/10.5038/1827-806X.50.1.2380

Gillmore, G. K., Sperrin, M., Phillips, P., \& Denman, A. (2000). Radon hazards, geology, and exposure of cave users: A case study and some theoretical perspectives. Ecotoxicology and Environmental Safety, 46(3), 279-288. https://doi.org/10.1006/eesa.2000.1922

Godefroy, N., Le Goff, E., Martinand-Mari, C., Belkhir, K., Vacelet, J., \& Baghdiguian, S. (2019). Sponge digestive system diversity and evolution: Filter feeding to carnivory. Cell and Tissue Research, 377(3), 341351. https://doi.org/10.1007/s00441-019-03032-8

Goldstein, B., \& King, N. (2016). The future of cell biology: Emerging model organisms. Trends in Cell Biology, 26(11), 818-824. https://doi. org/10.1016/j.tcb.2016.08.005

Gonzalez, B. C., Martínez, A., Borda, E., Iliffe, T. M., Fontaneto, D., \& Worsaae, K. (2017). Genetic spatial structure of an anchialine cave annelid indicates connectivity within - But not between - Islands of the Great Bahama Bank. Molecular Phylogenetics and Evolution, 109, 259-270. https://doi.org/10.1016/j.ympev.2017.01.003

Gorički, Š., Stanković, D., Snoj, A., Kuntner, M., Jeffery, W. R., Trontelj, P., Pavićević, M., Grizelj, Z., Năpăruş-Aljančič, M., \& Aljančič, G. (2017). Environmental DNA in subterranean biology: Range extension and taxonomic implications for Proteus. Scientific Reports, 7, 91-93. https://doi.org/10.1038/srep45054

Gravish, N., \& Lauder, G. V. (2018). Robotics-inspired biology. Journal of Experimental Biology, 221, jeb138438. https://doi.org/10.1242/ jeb.138438

Grimm, V., \& Berger, U. (2016). Structural realism, emergence, and predictions in next-generation ecological modelling: Synthesis from a special issue. Ecological Modelling, 326, 177-187. https://doi. org/10.1016/j.ecolmodel.2016.01.001 
Grimm, V., Revilla, E., Berger, U., Jeltsch, F., Mooij, W. M., Railsback, S. F., DeAngelis, D. L. (2005). Pattern-oriented modeling of agent-based complex systems: Lessons from ecology. Science, 310(5750), 987991. https://doi.org/10.1126/science.1116681

Hancock, P. J., \& Boulton, A. J. (2009). Sampling groundwater fauna: Efficiency of rapid assessment methods tested in bores in eastern Australia. Freshwater Biology, 54, 902-914. https://doi. org/10.1111/j.1365-2427.2007.01878.x

Hartig, F., Calabrese, J. M., Reineking, B., Wiegand, T., \& Huth, A. (2011). Statistical inference for stochastic simulation models Theory and application. Ecology Letters, 14(8), 816-827. https://doi. org/10.1111/j.1461-0248.2011.01640.x

Hedges, S. B. (2002). The origin and evolution of model organisms. Nature Reviews Genetics, 3(11), 838-849. https://doi.org/10.1038/nrg929

Hesselberg, T. (2010). Ontogenetic changes in web design in two orb-web spiders. Ethology, 116, 535-545. https://doi. org/10.1111/j.1439-0310.2010.01760.x

Hesselberg, T. (2015). Exploration behaviour and behavioural flexibility in orb-web spiders: A review. Current Zoology, 61(2), 313-327. https://doi.org/10.1093/czoolo/61.2.313

Hesselberg, T., Simonsen, D., \& Juan, C. (2019). Do cave orb spiders show unique behavioural adaptations to subterranean life? A review of the evidence. Behaviour, 156(10), 969-996. https://doi. org/10.1163/1568539X-00003564

Hortal, J., de Bello, F., Diniz-Filho, J. A. F., Lewinsohn, T. M., Lobo, J. M., \& Ladle, R. J. (2015). Seven shortfalls that beset large-scale knowledge of biodiversity. Annual Review of Ecology, Evolution, and Systematics, 46, 523-549. https://doi.org/10.1146/annurev-ecolsys-11241 $4-054400$

Howarth, F. G. (1983). Ecology of cave arthropods. Annual Review of Entomology, 28(1), 365-389. https://doi.org/10.1146/annur ev.en.28.010183.002053

Humphreys, W. F., Poole, A., Eberhard, S. M., \& Warren, D. (1999). Effects of research diving on the physico-chemical profile of Bundera Sinkhole, an anchialine remiped habitat at Cape Range, Western Australia. Journal of the Royal Society of Western Australia, 82, 99-108.

Hunt, P. J., Harden, T. J., Hibbins, M., Pritchard, R. C., Muir, D. B., \& Gardner, F. J. (1984). Histoplasma capsulatum. Isolation from an Australian cave environment and from a patient. The Medical Journal of Australia, 141(5), 280-283.

Iliffe, T. M. (2018). Collecting and processing crustaceans from anchialine and marine caves. Journal of Crustacean Biology, 38(3), 374-379. https://doi.org/10.1093/jcbiol/ruy011

Iliffe, T. M., \& Bowen, C. (2001). Scientific cave diving. Marine Technology Society Journal, 35(2), 36-41. https://doi.org/10.4031/0025332017 88001901

Jaggard, J. B., Stahl, B. A., Lloyd, E., Prober, D. A., Duboue, E. R., \& Keene, A. C. (2018). Hypocretin underlies the evolution of sleep loss in the Mexican cavefish. Elife, 7, e32637. https://doi.org/10.7554/ eLife.32637

Jeffery, W. R. (2020). Astyanax surface and cave fish morphs. EvoDevo, 11(1), 14. https://doi.org/10.1186/s13227-020-00159-6

Juan, C., Guzik, M. T., Jaume, D., \& Cooper, S. J. B. (2010). Evolution in caves: Darwin's 'wrecks of ancient life' in the molecular era. Molecular Ecology, 19(18), 3865-3880. https://doi. org/10.1111/j.1365-294X.2010.04759.x

Juberthie, C. (1985). Cycle vital de Telema tenella dans la GrotteLaboratoire de Moulis et strategies de reproduction chez les Araignees cavernicoles. Memoires De Biospeologie, 12, 77-89.

Juberthie, C., Durand, J., \& Dupuy, M. (1996). La reproduction des Protées (Proteus anguinus): Bilan de 35 ans d'élevage dans les grotteslaboratoires de Moulis et d'Aulignac. Memoires De Biospeologie, 23, 53-56.
Jurado-Rivera, J. A., Pons, J., Alvarez, F., Botello, A., Humphreys, W. F., Page, T. J., Iliffe, T. M., Willassen, E., Meland, K., Juan, C., \& Jaume, D. (2017). Phylogenetic evidence that both ancient vicariance and dispersal have contributed to the biogeographic patterns of anchialine cave shrimps. Scientific Reports, 7(1), 2852. https://doi.org/10.1038/ s41598-017-03107-y

Keene, A. C., Yoshizawa, M., \& McGaugh, S. E. (2016). Biology and evolution of the Mexican cavefish. Academic Press (Elsevier).

Keith, D. A., Ferrer-Paris, J. R., Nicholson, E., \& Kingsford, R. T. (2020). The IUCN Global Ecosystem Typology 2.0: Descriptive profiles for biomes and ecosystem functional groups. IUCN. https://doi.org/10.2305/ IUCN.CH.2020.13.en

Kim, M., \& Or, D. (2016). Individual-based model of microbial life on hydrated rough soil surfaces. PLoS One, 11(1), e0147394. https://doi. org/10.1371/journal.pone.0147394

Koenemann, S., Schram, F. R., Iliffe, T. M., Hinderstein, L. M., \& Bloechl, A. (2007). Behavior of remipedia in the laboratory, with supporting field observations. Journal of Crustacean Biology, 27(4), 534-540. https://doi.org/10.1651/S-2809A.1

Kolicka, M., Gadawski, P., \& Dabert, M. (2017). A new species of freshwater Chaetonotidae (Gastrotricha, Chaetonotida) from Obodska Cave (Montenegro) based on morphological and molecular characters. European Journal of Taxonomy, 354, 1-30.

Kuzmin, I. V., Bozick, B., Guagliardo, S. A., Kunkel, R., Shak, J. R., Tong, S., \& Rupprecht, C. E. (2011). Bats, emerging infectious diseases, and the rabies paradigm revisited. Emerging Health Threats Journal, 4(1), 7159. https://doi.org/10.3402/ehtj.v4i0.7159

Kuzmin, I. V., Niezgoda, M., Franka, R., Agwanda, B., Markotter, W., Breiman, R. F., Shieh, W.-J., Zaki, S. R., \& Rupprecht, C. E. (2010). Marburg virus in fruit bat, Kenya. Emerging Infectious Disease Journal, 16(2), 352. https://doi.org/10.3201/eid1602.091269

Lenau, T. A., Metze, A.-L., \& Hesselberg, T. (2018). Paradigms for biologically inspired design. In Paradigms for biologically inspired design ( $p$. 1059302). Proceedings Volume 10593, Bioinspiration, Biomimetics, and Bioreplication VIII. https://doi.org/10.1117/12.2296560

Lepore, E., Marchioro, A., Isaia, M., Buehler, M. J., \& Pugno, N. M. (2012). Evidence of the most stretchable egg sac silk stalk, of the European spider of the year meta menardi. PLoS One, 7(2), e30500. https://doi. org/10.1371/journal.pone.0030500

Lozano-Fernandez, J., Carton, R., Tanner, A. R., Puttick, M. N., Blaxter, M., Vinther, J., Olesen, J., Giribet, G., Edgecombe, G. D., \& Pisani, D. (2016). A molecular palaeobiological exploration of arthropod terrestrialization. Philosophical Transactions of the Royal Society B: Biological Sciences, 371(1699), 20150133. https://doi.org/10.1098/ rstb.2015.0133

Lunghi, E. (2018). Ecology and life history of Meta bourneti (Araneae: Tetragnathidae) from Monte Albo (Sardinia, Italy). PeerJ, 6, e6049. https://doi.org/10.7717/peerj.6049

Lunghi, E., Cianferoni, F., Ceccolini, F., Veith, M., Manenti, R., Mancinelli, G., Corti, C., \& Ficetola, G. F. (2018). What shapes the trophic niche of European plethodontid salamanders? PLoS One, 13, e0205672. https://doi.org/10.1371/journal.pone.0205672

Lunghi, E., Corti, C., Manenti, R., Barzaghi, B., Buschettu, S., Canedoli, C., \& Ficetola, G. F. (2018). Comparative reproductive biology of European cave salamanders (genus Hydromantes): Nesting selection and multiple annual breeding. Salamandra, 54, 101-108.

Lunghi, E., Corti, C., Mulargia, M., Zhao, Y., Manenti, R., Ficetola, G. F., \& Veith, M. (2020). Cave morphology, microclimate and abundance of five cave predators from the Monte Albo (Sardinia, Italy). Biodiversity Data Journal, 8, e48623. https://doi.org/10.3897/ BDJ.8.e48623

Lunghi, E., Ficetola, G. F., Mulargia, M., Cogoni, R., Veith, M., Corti, C., \& Manenti, R. (2018). Batracobdella leeches, environmental features and Hydromantes salamanders. International Journal for Parasitology: 
Parasites and Wildlife, 7, 48-53. https://doi.org/10.1016/j. ijppaw.2018.01.003

Lunghi, E., Manenti, R., Canciani, G., Scarì, G., Pennati, R., \& Ficetola, G. F. (2016). Thermal equilibrium and temperature differences among body regions in European plethodontid salamanders. Journal of Thermal Biology, 60, 79-85. https://doi.org/10.1016/j.jther bio.2016.06.010

Lunghi, E., Manenti, R., Cianferoni, F., Ceccolini, F., Veith, M., Corti, C., Ficetola, G. F., \& Mancinelli,, G. (2020). Interspecific and interpopulation variation in individual diet specialization: Do environmental factors have a role? Ecology, 101(8), e03088. https://doi.org/10.1002/ ecy.3088

Lunghi, E., Manenti, R., Manca, S., Mulargia, M., Pennati, R., \& Ficetola, G. F. (2014). Nesting of cave salamanders (Hydromantes flavus and $H$. italicus) in natural environments. Salamandra, 50, 105-109.

Lunghi, E., Murgia, R., De Falco, G., Buschettu, S., Mulas, C., Mulargia, M., \& Ficetola, G. F. (2015). First data on nesting ecology and behaviour in the imperial cave salamander Hydromantes imperialis. NorthWestern Journal of Zoology, 11, 324-330.

MacFarlane, D., \& Rocha, R. (2020). Guidelines for communicating about bats to prevent persecution in the time of COVID-19. Biological Conservation, 248, 108650. https://doi.org/10.1016/j. biocon.2020.108650

MacNeil, R. R., \& Brcic, J. (2017). Coping with the subterranean environment: A thematic content analysis of the narratives of cave explorers. Journal of Human Performance in Extreme Environments, 13(1), 6. https://doi.org/10.7771/2327-2937.1089

Maher, B. (2009). Evolution: Biology's next top model? Nature, 458, 695699. https://doi.org/10.1038/458695a

Malard, F., Grison, P., Duchemin, L., Konecny-Dupré, L., Lefébure, T., Saclier, N., Eme, D., Martin, C., Callou, C., \& Douady, C. J. (2020). GOTIT: A laboratory application software for optimizing multicriteria species-based research. Methods in Ecology and Evolution, 11(1), 159-167. https://doi.org/10.1111/2041-210X.13307

Mammola, S. (2019). Finding answers in the dark: Caves as models in ecology fifty years after Poulson and White. Ecography, 42(7), 13311351. https://doi.org/10.1111/ecog.03905

Mammola, S. (2020). On deepest caves, extreme habitats, and ecological superlatives. Trends in Ecology \& Evolution, 35(6), 469-472. https:// doi.org/10.1016/j.tree.2020.02.011

Mammola, S., Amorim, I. R., Bichuette, M. E., Borges, P. A. V., Cheeptham, N., Cooper, S. J. B., Culver, D. C., Deharveng, L., Eme, D., Ferreira, R. L., Fišer, C., Fišer, Ž., Fong, D. W., Griebler, C., Jeffery, W. R., Jugovic, J., Kowalko, J. E., Lilley, T. M., Malard, F., ... Cardoso, P. (2020). Fundamental research questions in subterranean biology. Biological Reviews, 95(6), 1855-1872. https://doi.org/10.1111/brv.12642

Mammola, S., Cardoso, P., Culver, D. C., Deharveng, L., Ferreira, R. L., Fišer, C., Galassi, D. M. P., Griebler, C., Halse, S., Humphreys, W. F., Isaia, M., Malard, F., Martinez, A., Moldovan, O. T., Niemiller, M. L., Pavlek, M., Reboleira, A. S. P. S., Souza-Silva, M., Teeling, E. C., ... Zagmajster, M. (2019). Scientists' warning on the conservation of subterranean ecosystems. BioScience, 69(8), 641-650. https://doi. org/10.1093/biosci/biz064

Mammola, S., Giachino, P. M., Piano, E., Jones, A., Barberis, M., Badino, G., \& Isaia, M. (2016). Ecology and sampling techniques of an understudied subterranean habitat: The Milieu Souterrain Superficiel (MSS). The Science of Nature, 103(11-12), 88. https://doi.org/10.1007/s0011 4-016-1413-9

Mammola, S., \& Isaia, M. (2017). Spiders in caves. Proceedings of the Royal Society B: Biological Sciences, 284(1853), 20170193. https://doi. org/10.1098/rspb.2017.0193

Mammola, S., \& Isaia, M. (2018). Day-night and seasonal variations of a subterranean invertebrate community in the twilight zone. Subterranean Biology, 27, 31-51. https://doi.org/10.3897/SUBTB IOL.27.28909
Mammola, S., \& Leroy, B. (2018). Applying species distribution models to caves and other subterranean habitats. Ecography, 41(7), 1194-1208. https://doi.org/10.1111/ecog.03464

Mammola, S., Piano, E., Malard, F., Vernon, P., \& Isaia, M. (2019). Extending Janzen's hypothesis to temperate regions: A test using subterranean ecosystems. Functional Ecology, 33(9), 1638-1650. https://doi.org/10.1111/1365-2435.13382

Mammola, S., Souza, M. F. V. R., Isaia, M., \& Ferreira, R. L. (2021). Global distribution of microwhip scorpions (Arachnida: Palpigradi). Journal of Biogeography, 00, 1-13. https://doi.org/10.1111/jbi.14094

Manenti, R., Barzaghi, B., Lana, E., Stocchino, G. A., Manconi, R., \& Lunghi, E. (2018). The stenoendemic cave-dwelling planarians (Platyhelminthes, Tricladida) of the Italian Alps and Apennines: Conservation issues. Journal for Nature Conservation, 45, 90-97. https://doi.org/10.1016/j.jnc.2018.08.001

Manenti, R., Melotto, A., Guillaume, O., Ficetola, G. F., \& Lunghi, E. (2020). Switching from mesopredator to apex predator: How do responses vary in amphibians adapted to cave living? Behavioral Ecology and Sociobiology, 74, 126. https://doi.org/10.1007/s00265-020-02909-x

Martínez, A., Di Domenico, M., Leasi, F., Curini-Galletti, M., Todaro, M. A., Zotto, M. D., Gobert, S., Artois, T., Norenburg, J., Jörger, K. M., Núñez, J., Fontaneto, D., \& Worsaae, K. (2019). Patterns of diversity and endemism of soft-bodied meiofauna in an oceanic island, Lanzarote, Canary Islands. Marine Biodiversity, 49, 2033-2055. https://doi.org/10.1007/s12526-019-01007-0

Martínez, A., Di Domenico, M., \& Worsaae, K. (2013). Evolution of cave Axiokebuita and Speleobregma (Scalibregmatidae, Annelida). Zoologica Scripta, 42(6), 623-636. https://doi.org/10.1111/zsc.12024

Martínez, A., Kvindebjerg, K., lliffe, T. M., \& Worsaae, K. (2017). Evolution of cave suspension feeding in Protodrilidae (Annelida). Zoologica Scripta, 46(2), 214-226. https://doi.org/10.1111/zsc.12198

Martínez, A., \& Mammola, S. (2020). Let research on subterranean habitats resonate!. Subterranean Biology, 36, 63-71. https://doi. org/10.3897/subtbiol.36.59960

McGaugh, S. E., Kowalko, J. E., Duboué, E., Lewis, P., Franz-Odendaal, T. A., Rohner, N., Gross, J. B., \& Keene, A. C. (2020). Dark world rises: The emergence of cavefish as a model for the study of evolution, development, behavior, and disease. Journal of Experimental Zoology Part B: Molecular and Developmental Evolution, 334(7-8), 397-404. https://doi.org/10.1002/jez.b.22978

Mermillod-Blondin, F., Lefour, C., Lalouette, L., Renault, D., Malard, F., Simon, L., \& Douady, C. J. (2013). Thermal tolerance breadths among groundwater crustaceans living in a thermally constant environment. The Journal of Experimental Biology, 216(9), 1683-1694. https://doi. org/10.1242/jeb.081232

Moldovan, O. T., Mihevc, A., Miko, L., Constantin, S., Meleg, I. N., Petculescu, A., \& Bosák, P. (2011). Invertebrate fossils from cave sediments: A new proxy for pre-Quaternary paleoenvironments. Biogeosciences, 8(7), 1825-1837. https://doi.org/10.5194/ bg-8-1825-2011

Moseley, M. (2009). Size matters: Scalar phenomena and a proposal for an ecological definition of 'cave'. Cave and Karst Science, 35, 89-94.

Möst, M. H., Donabauer, M., Arthofer, W., Schlick-Steiner, B. C., \& Steiner, F. M. (2020). Towards an evolutionary history of EuropeanAlpine Trechus ground beetles: Species groups and wing reduction. Molecular Phylogenetics and Evolution, 149, 106822. https://doi. org/10.1016/j.ympev.2020.106822

Müller, B., \& Grossniklaus, U. (2010). Model organisms - A historical perspective. Journal of Proteomics, 73(11), 2054-2063. https://doi. org/10.1016/j.jprot.2010.08.002

Niemiller, M. L., Near, T. J., \& Fitzpatrick, B. M. (2012). Delimiting species using multilocus data: Diagnosing cryptic diversity in the southern cavefish, Typhlichthys subterraneus (Teleostei: Amblyopsidae). Evolution, 66(3), 846-866. https://doi. org/10.1111/j.1558-5646.2011.01480.x 
Niemiller, M. L., Porter, M. L., Keany, J., Gilbert, H., Fong, D. W., Culver, D. C., Hobson, C. S., Kendall, K. D., Davis, M. A., \& Taylor, S. J. (2018). Evaluation of eDNA for groundwater invertebrate detection and monitoring: A case study with endangered Stygobromus (Amphipoda: Crangonyctidae). Conservation Genetics Resources, 10, 247-257. https://doi.org/10.1007/s12686-017-0785-2

Northup, D. E., Melim, L. A., Spilde, M. N., Hathaway, J., Garcia, M. G., Moya, M., Stone, F. D., Boston, P. J., Dapkevicius, M., \& Riquelme, C. (2011). Lava cave microbial communities within mats and secondary mineral deposits: Implications for life detection on other planets. Astrobiology, 11, 601-618. https://doi.org/10.1089/ast.2010.0562

Oliveira, M. P. A. D., Bastos-Pereira, R., Torres, S. H. S., Pereira, T. S., Batista, F. M., Alves, J. P., Iniesta, L. F. M., Bouzan, R. S., Chagas-Jr, A., Prous, X., Pietrobon, T., \& Ferreira, R. L. (2019). Choosing sampling methods for Chilopoda, Diplopoda and Isopoda (Oniscidea): A case study for ferruginous landscapes in Brazilian Amazonia. Applied Soil Ecology, 143, 181-191. https://doi.org/10.1016/j.apsoil.2019.07.012

Oneto, F., Ottonello, D., Pastorino, M. V., \& Salvidio, S. (2010). Posthatching parental care in salamanders revealed by infrared video surveillance. Journal of Herpetology, 44, 649-653. https://doi. org/10.1670/09-181.1

Pallarés, S., Colado, R., Botella-Cruz, M., Montes, A., Balart-García, P., Bilton, D. T., Millán, A., Ribera, I., \& Sánchez-Fernández, D. (2020). Loss of heat acclimation capacity could leave subterranean specialists highly sensitive to climate change. Animal Conservation, Epub ahead of print. https://doi.org/10.1111/acv.12654

Pallarés, S., Sanchez-Hernandez, J. C., Colado, R., Balart-García, P., Comas, J., \& Sánchez-Fernández, D. (2020). Beyond survival experiments: Using biomarkers of oxidative stress and neurotoxicity to assess vulnerability of subterranean fauna to climate change. Conservation Physiology, 8(1), https://doi.org/10.1093/conphys/ coaa067

Parzefall, J. (1982). Changement of behaviour during the evolution of cave animals. Memoires De Biospeologie, 8, 55-62.

Pérez-Moreno, J. L., lliffe, T. M., \& Bracken-Grissom, H. D. (2016). Life in the Underworld: Anchialine cave biology in the era of speleogenomics. International Journal of Speleology, 49, 149-170. https://doi. org/10.5038/1827-806X.45.2.1954

Pfeifer, R., Lungarella, M., \& lida, F. (2007). Self-organization, embodiment, and biologically inspired robotics. Science, 318, 1088-1093. https://doi.org/10.1126/science.1145803

Polak, S. (1997). A classification of the subterranean environment and cave fauna. Acta Carsologica, 26(2), 351-359.

Poulson, T. L., \& White, W. B. (1969). The cave environment. Science, 165(3897), 971-981. https://doi.org/10.1126/science.165.3897.971

Protas, M., \& Jeffery, W. R. (2012). Evolution and development in cave animals: From fish to crustaceans. Wiley Interdisciplinary Reviews. Developmental Biology, 1(6), 823-845. https://doi.org/10.1002/ wdev.61

Rastorgueff, P. A., Rocher, C., Selva, M., \& Chevaldonné, P. (2015). Preliminary DNA-based diet assessment of a gutless carnivore, the sponge Asbestopluma hypogea. Journal of Experimental Marine Biology and Ecology, 467, 108-114. https://doi.org/10.1016/j. jembe.2015.02.014

Riddle, M. R., Aspiras, A. C., Gaudenz, K., Peuß, R., Sung, J. Y., Martineau, B., Peavey, M., Box, A. C., Tabin, J. A., McGaugh, S., Borowsky, R., Tabin, C. J., \& Rohner, N. (2018). Insulin resistance in cavefish as an adaptation to a nutrient-limited environment. Nature, 555, 647. https://doi.org/10.1038/nature26136

Rocha, R., Aziz, S. A., Brook, C. E., Carvalho, W. D., Cooper-Bohannon, R., Frick, W. F., Huang, J.-C.-C., Kingston, T., López-Baucells, A., Maas, B., Mathews, F., Medellin, R. A., Olival, K. J., Peel, A. J., Plowright, R. K., Razgour, O., Rebelo, H., Rodrigues, L., Rossiter, S. J., ... Webala, P. W. (2020). Bat conservation and zoonotic disease risk: A research agenda to prevent misguided persecution in the aftermath of COVID-19. Animal Conservation, Epub ahead of print. https://doi. org/10.1111/acv.12636

Ross, P. A., Endersby-Harshman, N. M., \& Hoffmann, A. A. (2019). A comprehensive assessment of inbreeding and laboratory adaptation in Aedes aegypti mosquitoes. Evolutionary Applications, 12(3), 572-586. https://doi.org/10.1111/eva.12740

Russell, J. J., Theriot, J. A., Sood, P., Marshall, W. F., Landweber, L. F., FritzLaylin, L., Polka, J. K., Oliferenko, S., Gerbich, T., Gladfelter, A., Umen, J., Bezanilla, M., Lancaster, M. A., He, S., Gibson, M. C., Goldstein, B., Tanaka, E. M., Hu, C.-K., \& Brunet, A. (2017). Non-model model organisms. BMC Biology, 15(1), 1-31. https://doi.org/10.1186/s1291 5-017-0391-5

Saccò, M., Blyth, A., Bateman, P. W., Hua, Q., Mazumder, D., White, N., Humphreys, W. F., Laini, A., Griebler, C., \& Grice, K. (2019). New light in the dark - A proposed multidisciplinary framework for studying functional ecology of groundwater fauna. Science of the Total Environment, 662, 963-977. https://doi.org/10.1016/j.scito tenv.2019.01.296

Saccò, M., Blyth, A. J., Humphreys, W. F., Karasiewicz, S., Meredith, K. T., Laini, A., Cooper, S. J. B., Bateman, P. W., \& Grice, K. (2020). Stygofaunal community trends along varied rainfall conditions: Deciphering ecological niche dynamics of a shallow calcrete in Western Australia. Ecohydrology, 13(1), e2150. https://doi. org/10.1002/eco.2150

Sánchez, N., \& Martínez, A. (2019). Dungeons and dragons: Two new species and records of Kinorhyncha from anchialine cenotes and marine lava tubes. Zoologischer Anzeiger, 282, 161-175. https://doi. org/10.1016/j.jcz.2019.05.012

Schmidt, S. I., Hahn, H. J., Watson, G. D., Woodbury, R. J., \& Hatton, T. J. (2004). Sampling fauna in stream sediments as well as groundwater using one net sampler. Acta Hydrochimica Et Hydrobiologica, 32, 131137. https://doi.org/10.1002/aheh.200300522

Schmidt, S. I., Kreft, J.-U., Mackay, R., Picioreanu, C., \& Thullner, M. (2018). Elucidating the impact of micro-scale heterogeneous bacterial distribution on biodegradation. Advances in Water Resources, 116, 67-76. https://doi.org/10.1016/j.advwatres.2018.01.013

Schmidt-Rhaesa, A. (2020). Guide to the identification of marine meiofauna. Verlag Dr Friedrich Pfeil.

Sendra, A., Antić, D., Barranco, P., Borko, Š., Christian, E., Delić, T., \& Reboleira, A. S. P. (2020). Flourishing in subterranean ecosystems: Euro-mediterranean plusiocampinae and tachycampoids (Diplura, Campodeidae). European Journal of Taxonomy, 591, 1-138.

Sendra, A., Palero, F., Jiménez-Valverde, A., \& Reboleira, A. S. P. S. (2020). Diplura in caves: Diversity, ecology, evolution and biogeography. Zoological Journal of the Linnean Society, 20, 1-15. https://doi. org/10.1093/zoolinnean/zlaa116

Smithers, P. (2005). The early life history and dispersal of the cave spider Meta menardi (Latreille, 1804) (Araneae: Tetragnathidae). Bulletin of the British Arachnological Society, 13(6), 213-216. https://doi. org/10.1636/CT-05-2.1

Staffolani, S., Buonfrate, D., Angheben, A., Gobbi, F., Giorli, G., Guerriero, M., Bisoffi, Z., \& Barchiesi, F. (2018). Acute histoplasmosis in immunocompetent travelers: A systematic review of literature. BMC Infectious Diseases, 18(1), 673. https://doi.org/10.1186/s1287 9-018-3476-z

Stemme, T., lliffe, T. M., von Reumont, B. M., Koenemann, S., Harzsch, S., \& Bicker, G. (2013). Serotonin-immunoreactive neurons in the ventral nerve cord of Remipedia (Crustacea): Support for a sister group relationship of Remipedia and Hexapoda? BMC Evolutionary Biology, 13(1), 119. https://doi.org/10.1186/1471-2148-13-119

Stockdale, W. T., Lemieux, M. E., Killen, A. C., Zhao, J., Hu, Z., Riepsaame, J., Hamilton, N., Kudoh, T., Riley, P. R., van Aerle, R., Yamamoto, Y., \& Mommersteeg, M. T. M. (2018). Heart regeneration in the Mexican cavefish. Cell Reports, 25(8), 1997-2007.e7. https://doi.org/10.1016/j. celrep.2018.10.072 
Sullivan, W. (2015). The institute for the study of non-model organisms and other fantasies. Molecular Biology of the Cell, 26(3), 387-389. https://doi.org/10.1091/mbc.E14-03-0814

Swann, D. E., Hass, C. C., Dalton, D. C., \& Wolf, S. A. (2004). Infraredtriggered cameras for detecting wildlife: An evaluation and review. Wildlife Society Bulletin, 32, 357-365. https://doi.org/10.2193/00917648(2004)32[357:icfdwa]2.0.co;2

Tang, Y., Valocchi, A. J., Werth, C. J., \& Liu, H. (2013). An improved porescale biofilm model and comparison with a microfluidic flow cell experiment. Water Resources Research, 49(12), 8370-8382. https://doi. org/10.1002/2013WR013843

Torres-Paz, J., Hyacinthe, C., Pierre, C., \& Rétaux, S. (2018). Towards an integrated approach to understand Mexican cavefish evolution. Biology Letters, 14(8), 20180101. https://doi.org/10.1098/ rsbl.2018.0101

Trajano, E., \& Bichuette, M. E. (2010). Diversity of Brazilian subterranean invertebrates, with a list of troglomorphic taxa. Subterranean Biology, 7, 1-16.

Trajano, E., Gallão, J. E., \& Bichuette, M. E. (2016). Spots of high diversity of troglobites in Brazil: The challenge of measuring subterranean diversity. Biodiversity and Conservation, 25(10), 1805-1828. https://doi. org/10.1007/s10531-016-1151-5

Uéno, S.-I. (1987). The derivation of terrestrial cave animals. Zoological Science, 4, 593-606.

Verovnik, R., Sket, B., \& Trontelj, P. (2004). Phylogeography of subterranean and surface populations of water lice Asellus aquaticus (Crustacea: Isopoda). Molecular Ecology, 13, 1519-1532. https://doi. org/10.1111/j.1365-294X.2004.02171.x

Vincent, J. F. V., Bogatyreva, O. A., Bogatyrev, N. R., Bowyer, A., \& Pahl, A.-K. (2006). Biomimetics: Its practice and theory. Journal of the Royal Society Interface, 3(9), 471-482. https://doi.org/10.1098/ rsif.2006.0127

Voituron, Y., De Fraipont, M., Issartel, J., Guillaume, O., \& Clobert, J. (2011). Extreme lifespan of the human fish (Proteus anguinus): A challenge for ageing mechanisms. Biology Letters, 7, 105-107. https:// doi.org/10.1098/rsbl.2010.0539

Vollrath, F., \& Selden, P. (2007). The role of behavior in the evolution of spiders, silks, and webs. Annual Review of Ecology, Evolution, and Systematics, 38, 819-846. https://doi.org/10.1146/annurev.ecols ys.37.091305.110221

von Reumont, B. M., Blanke, A., Richter, S., Alvarez, F., Bleidorn, C., \& Jenner, R. A. (2014). The first venomous crustacean revealed by transcriptomics and functional morphology: Remipede venom glands express a unique toxin cocktail dominated by enzymes and a neurotoxin. Molecular Biology and Evolution, 31(1), 48-58. https://doi. org/10.1093/molbev/mst199

Weinstein, P., \& Slaney, D. (1995). Invertebrate faunal survey of rope ladder cave, northern Queensland: A comparative study of sampling methods. Australian Journal of Entomology, 34(3), 233-236. https:// doi.org/10.1111/j.1440-6055.1995.tb01329.x

Wiegand, T., Revilla, E., \& Knauer, F. (2004). Dealing with uncertainty in spatially explicit population models. Biodiversity and Conservation, 13(1), 53-57. https://doi.org/10.1023/B:BIOC.0000004313.86836.ab
Wilkens, H. (1971). Genetic interpretation of regressive evolutionary processes: Studies on hybrid eyes of two Astyanax cave populations (Characidae, Pisces). Evolution, 25(3), 530-544. https://doi. org $/ 10.2307 / 2407352$

Wilkens, H., Parzefall, J., \& lliffe, T. M. (1986). Origin and age of the marine Stygofauna of Lanzarote, Canary Islands. Mitteilungen Aus Den Hamburgischen Zoologischen Museum Und Institut, 83, 223-230.

Woodward, M. A., \& Sitti, M. (2014). MultiMo-Bat: A biologically inspired integrated jumping-gliding robot. International Journal of Robotics Research, 33, 1511-1529. https://doi.org/10.1177/0278364914 541301

Wynne, J. J., Howarth, F. G., Sommer, S., \& Dickson, B. G. (2019). Fifty years of cave arthropod sampling: Techniques and best practices. International Journal of Speleology, 48(1), 33-48. https://doi. org/10.5038/1827-806X.48.1.2231

Wynne, J. J., Sommer, S., Howarth, F. G., Dickson, B. G., \& Voyles, K. D. (2018). Capturing arthropod diversity in complex cave systems. Diversity and Distributions, 24, 1478-1491. https://doi.org/10.1111/ ddi.12772

Yoshizawa, M., Settle, A., Hermosura, M. C., Tuttle, L. J., Cetraro, N., Passow, C. N., \& McGaugh, S. E. (2018). The evolution of a series of behavioral traits is associated with autism-risk genes in cavefish. BMC Evolutionary Biology, 18(1), 89. https://doi.org/10.1186/s1286 2-018-1199-9

Zagmajster, M., Culver, D. C., Christman, M. C., \& Sket, B. (2010). Evaluating the sampling bias in pattern of subterranean species richness: Combining approaches. Biodiversity and Conservation, 19(11), 3035-3048. https://doi.org/10.1007/s10531-010-9873-2

Zakšek, V., Sket, B., Gottstein, S., Franjević, D., \& Trontejl, P. (2009). The limits of cryptic diversity in groundwater: Phylogeography of the cave shrimp Troglocaris anophthalmus (Crustacea: Decapoda: Atyidae). Molecular Ecology, 18(5), 931-946. https://doi. org/10.1111/j.1365-294X.2008.04061.x

Zschokke, S., \& Herberstein, M. E. (2005). Laboratory methods for maintaining and studying web-building spiders. Journal of Arachnology, 33, 205-213. https://doi.org/10.1636/CT04-72.1

\section{SUPPORTING INFORMATION}

Additional supporting information may be found online in the Supporting Information section.

How to cite this article: Mammola S, Lunghi E, Bilandžija H, et al. Collecting eco-evolutionary data in the dark: Impediments to subterranean research and how to overcome them. Ecol Evol. 2021;11:5911-5926. https://doi.org/10.1002/ece3.7556 